\title{
Possible Origins of Till-Like Deposits Near the Summit of the Front Range in North-Central Colorado
}

GEOLOGICAL SURVEY PROFESSIONAL PAPIR I243

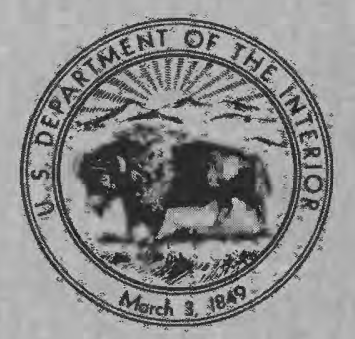


Possible Origins of Till-Like Deposits Near the Summit of the Front Range in North-Central Colorado

By RICHARD F. MADOLE

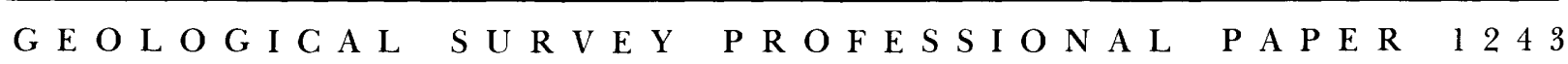

A description of two diamictons

previously mapped as till

and a reinterpretation of their origin.

Periglacial mass wasting, landslide,

glacial, and alluvial-colluvial

origins are considered

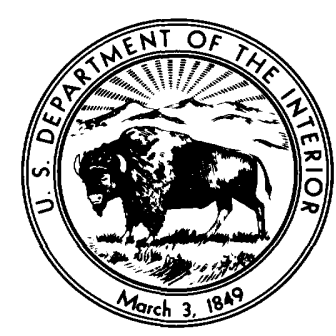

UNITED STATES GOVERNMENT PRINTING OFFICE, WASHINGTON : 1982 


\section{UNITED STATES DEPARTMENT OF THE INTERIOR}

JAMES G. WATT, Secretary

\section{GEOLOGICAL SURVEY}

Dallas L. Peck, Director

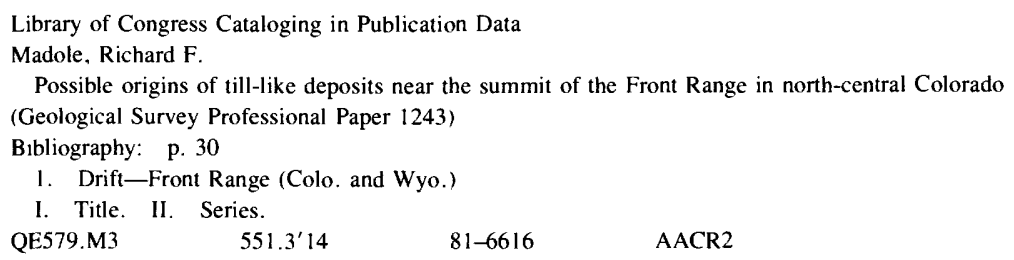

For sale by the Branch of Distribution, U.S. Geological Survey 604 South Pickett Street, Alexandria, VA 22304 


\title{
CONTENTS
}

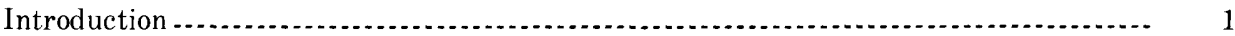

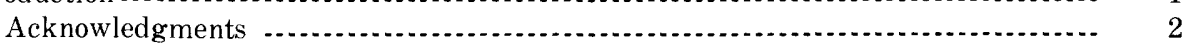 \\ Study sites \\ Sedimentary characteristics of the diamictons. $\ldots \ldots \ldots \ldots$ \\ Distribution, contacts, and thickness \\ Composition.

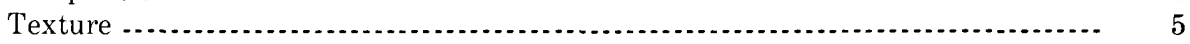

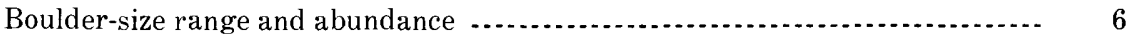

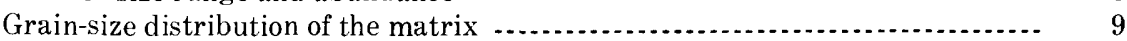

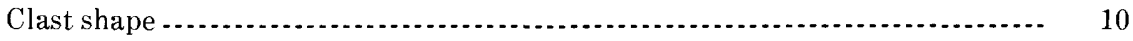

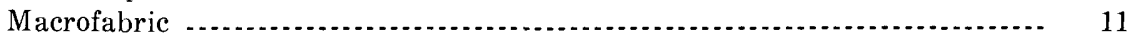

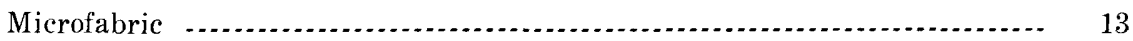 \\ Surface features of quartz grains ................. 13 \\ Possible origins for the diamictons $\ldots \ldots \ldots$ \\ Periglacial mass wasting deposits

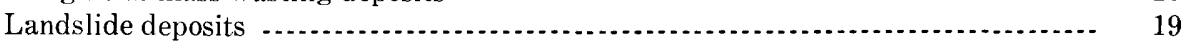 \\ Rockfall and rockslide avalanches......................................... 20

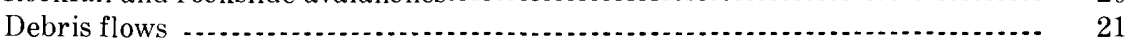

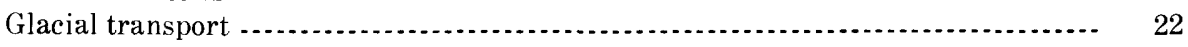

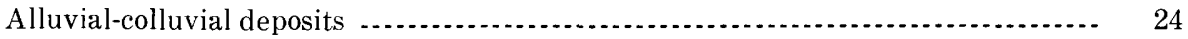

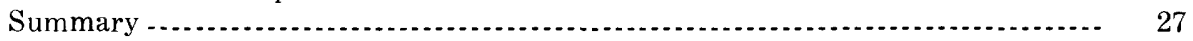

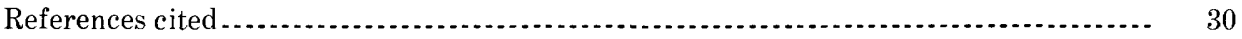

\section{ILLUSTRATIONS}

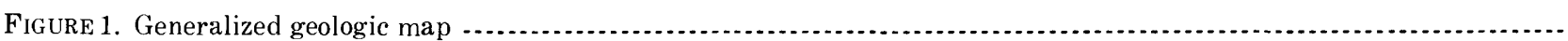

2. Oblique aerial view west across Niwot Ridge to the Continental Divide ..............................................

3. Map of rock units and the diamicton on Niwot Ridge and the composition of the diamicton ...........................

4. Diagram showing approximate thickness of the diamicton on Niwot Ridge.......................................

5. Map of rock units and the diamicton on the unnamed ridge north of Niwot Ridge, and the composition of the diamicton

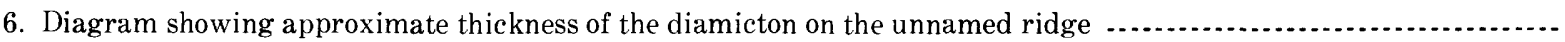

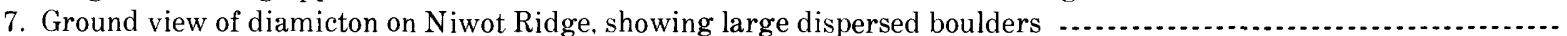

8. Graph of boulder abundance in the diamictons, till of Pinedale age, and residuum ....................................

9. Diagrams showing mean grain-size distribution of samples of the Cox horizon of soil profiles ...........................

10. Diagram comparing the angularity of megaclasts in till and outwash of Pinedale age, the diamictons, and residuum

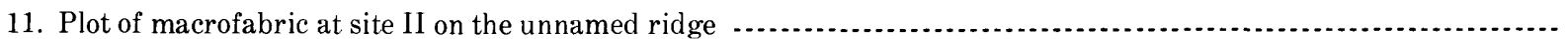

12-15. Scanning electron micrographs of:

12. Quartz grains from residuum

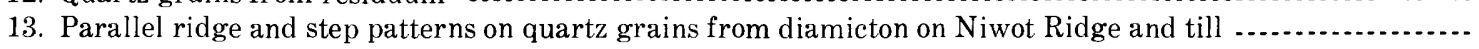

14. Arcuate patterns on quartz grains from diamicton on Niwot Ridge and till ...................................

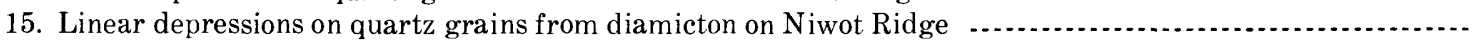

16. Oblique aerial view of diamicton on Niwot Ridge overlying Tertiary monzonite .......................................

17. Comparison of sorting, graphic mean plotted against inclusive graphic standard deviation ...........................

18. Photograph of alluvial and colluvial deposits on canyon floor of Cache la Poudre River ...............................

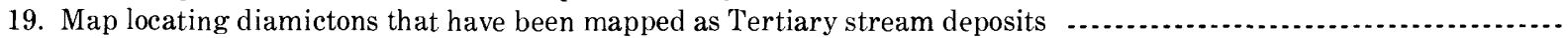

20. Photograph of diamicton mapped as boulder gravel capping a ridge in Squaw Pass quadrangle ..................... 
TABLES

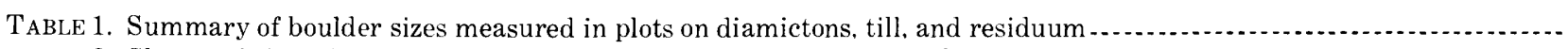

2. Shapes of clasts in the diamicton on Niwot Ridge and the unnamed ridge

Page

3. Summary of macrofabric data for the diamicton on the unnamed ridge

4. Comparison of mean vector and vector magnitude for the macrofabrics and microfabrics of the diamicton on the unnamed ridge

5. Surface features of quartz grains from four types of deposits investigated with the scanning

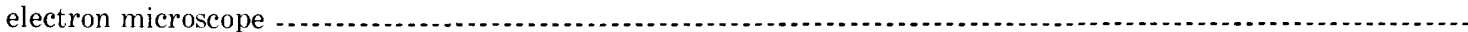




\title{
POSSIBLE ORIGINS OF TILL-LIKE DEPOSITS NEAR THE SUMMIT OF THE FRONT RANGE IN NORTH-CENTRAL COLORADO
}

\author{
By RICHARD F. MADOLE
}

\begin{abstract}
Diamictons cap ridges and fill U-shaped cols at several localities along the Continental Divide in the northern Front Range, northcentral Colorado. In the past, a few of the diamictons were mapped as till, chiefly because they contain many large boulders of exotic rocks in a poorly sorted matrix. However, four categories of deposits, all of which are common to this region, possess these characteristics. They include (1) periglacial mass wasting deposits; (2) landslide deposits; (3) glacial deposits; and (4) alluvial-colluvial deposits. Because the genesis of the diamictons profoundly influences the interpretation of the structural, erosional, and climatic histories of the region, two areas of diamictons, previously mapped as till, were restudied. The two areas are on Niwot Ridge and an unnamed ridge to the north, high interfluvial divides that extend east from the Continental Divide in western Boulder County, Colo.

Transport by slow mass movement in a periglacial environment is rejected as an origin for the diamictons, and an interpretation of origin by landsliding has several weaknesses. If ice were the transporting agent, the glaciers were small (less than $5 \mathrm{~km}$ from uppermost accumulation area to terminus) and not the large ice cap suggested by earlier workers. Even though the evidence does not unequivocally prove the origin of the diamictons, it suggests three arguments favoring the interpretation that they are mixtures of mostly alluvium and colluvium. These arguments are based on (1) the physical resemblance of the diamictons to bouldery deposits known to consist of alluvium, colluvium, and debris flow deposits; (2) the occurrence of similar diamictons in areas where glaciation cannot account for them, and (3) the probability that the diamictons are of Tertiary rather than Quaternary age because of the amount of erosion that has occurred since some of them were deposited.

The two diamictons studied, which were previously mapped as till of Quaternary age, are here interpreted to be aggregations of alluvium, colluvium, and possibly some debris flow deposits, which accumulated during Tertiary time on a surface of low relief that subsequently was uplifted and deeply dissected.
\end{abstract}

\section{INTRODUCTION}

Diamictons that consist of boulders in a poorly sorted, sandy matrix top ridge crests and fill cols at several localities along the summit of the northern Front Range. Diamicton is a nongenetic term for a poorly sorted terrestrial sediment containing a wide range of particle sizes, such as a till (Flint and others, $1960 \mathrm{a}, 1960 \mathrm{~b}$ ), and it is used here to avoid a genetic term for deposits whose origin is uncertain. The diamictons are texturally similar to late Pleistocene tills in nearby valleys, but they are older than the tills. The diamictons predate the formation of the deep valleys through which late Pleistocene valley glaciers moved, and they occur 200-400 $\mathrm{m}$ above the uppermost occurrence of till along adjacent valley sides. Morphologic characteristics of the deposits that could aid in interpreting their origin are absent from the diamictons, possibly because they are old and have been greatly modified by mass movement and erosion. Without landforms it is difficult to determine whether the deposits are till or some type of nonglacial deposit, because the sedimentological criteria of poor sorting and the presence of large boulders of exotic rock types are common to diamictons of several origins (Flint and others, 1960a; Harland and others, 1966). Faceted or striated clasts were not found in any of the diamictons examined, and weathering has long since erased any markings that might have been on the clasts at the surface. However, distinctively striated clasts are not common in the tills of the region, because the coarsegrained crystalline rocks that dominate these deposits do not striate readily.

Poorly sorted terrestrial deposits of Miocene to Quaternary age are widespread in the mountains of Colorado and probably are common to many parts of the Rocky Mountain region. Different origins assigned to these diamictons result in markedly different interpretations of the climatic, tectonic, and erosional histories of the region. Several deposits initially described as till in various publications (Atwood and Mather, 1932; Bryan and Ray, 1940; Eschman, 1955; Gable, 1972; Harris and Fahnestock, 1962; Ives, 1953; Moss, 1951; Madole, 1960; Ray, 1940; Richmond, 1948; 
Wahlstrom, 1940, 1947) were reinterpreted to be diamictons of nonglacial origin (Richmond, 1965, p. 217-218; Madole, 1976, p. 302-303). Accordingly, this has modified previous interpretations of glacial history.

This report summarizes evidence gathered from the study of two diamictons that previously were mapped as till (Wahlstrom, 1940, 1947; Ives, 1953; Madole, 1960 ) and that formed an integral part of Wahlstrom's (1947) work on the Front Range summit and subsummit erosion surface problem. The discussion concerning the origin of these two deposits is based chiefly on sedimentological data, because the deposits are relatively small and isolated and lack remains of landforms.

The first part of the report describes the sedimentary characteristics of the two diamictons, and the second presents four possible origins for the diamictons in terms of their sedimentary characteristics.

\section{ACKNOWLEDGMENTS}

The National Science Foundation College Teacher's Research Participation Program and Academic Year Extension Grant GY-5574 funded part of this work. James A. Clark provided invaluable assistance in the field throughout the summers of 1968 and 1969. Sharon Allred, Thomas Bassier, Nancy Finnegan, Holly Horton, Darv Lloyd, Barbara Madole, Mark Madole, Thomas Madole, Nancy McKinnie, and Harvey Moulton helped in various parts of the work involved in the seismic surveys, excavating pits and recording data for macrofabrics, measuring microfabrics, and evaluating the roundness of clasts in the deposits studied. Robert McGrew, Electron Microscopy Suite, Department of Molecular, Cellular, and Developmental Biology, University of Colorado, provided instruction in the operation of the scanning electron microscope. Charles Semmer and Ginger Wadleigh of the National Center for Atmospheric Research, Boulder, Colo., supplied the photographs for figures 2 and 16. The following individuals of the Institute of Arctic and Alpine Research gave assistance: J. T. Andrews and Nel Caine helped with the computer programs for till fabric analysis and reviewed a preliminary draft of this report; Larry Williams helped with computer programs for two-dimensional computer analysis of microfabrics; Rolf Kihl did grain-size analyses. K. L. Pierce, G. R. Scott, R. B. Taylor, D. A. Coates, G. A. Izett, and C. A. Wallace, U.S. Geological Survey, provided many helpful suggestions for improving the presentation of this study.

\section{STUDY SITES}

The diamictons chosen for study cap two ridges, Niwot Ridge and an unnamed ridge to the immediate north, that are high interfluvial divides extending east from the Continental Divide (fig. 1). These areas were the principal sites studied because the composition of the diamictons relative to that of the Audubon-Albion stock demonstrates that the diamictons were transported to their sites of deposition. Only a few of the diamictons along the summit of the northern Front Range can be shown unequivocally to have been transported for distances greater than would be expected by creep and solifluction. The diamictons on Niwot Ridge and the unnamed ridge to the north, however, can be shown to be far removed from their source. The cobbles and boulders in them, which (based on five measurements) make up an estimated 10-30 percent of the deposits, consist almost entirely of clasts derived from Proterozoic quartz monzonite and biotite gneiss (Wahlstrom, 1940, 1947; Gable and Madole, 1976); yet these diamictons overlie the Audubon-Albion stock (chiefly monzonite of Tertiary age). Hence, no ambiguity remains about whether these two diamictons were transported for considerable distances; the question is, how were they transported?

The diamictons on Niwor Ridge and the unnamed ridge to the north are at altitudes of about 3,450-3,720 $\mathrm{m}$, which, as shown in figures 1 and 2 , approaches the level of the Continental Divide. The deposit on the unnamed ridge is $100-140 \mathrm{~m}$ above timberline (altitude about 3,350 $\mathrm{m}$ ) and $155-290 \mathrm{~m}$ above adjacent valley floors. The deposit on Niwot Ridge is $100-240 \mathrm{~m}$ higher than that on the unnamed ridge and $260-440 \mathrm{~m}$ above the valley floors.

\section{SEDIMENTARY CHARACTERISTICS OF THE DIAMICTONS \\ DISTRIBUTION, CONTACTS, AND THICKNESS}

The diamicton on Niwot Ridge is about $2 \mathrm{~km}$ long, as much as $0.5 \mathrm{~km}$ wide, and according to seismic data, 3-36 $\mathrm{m}$ thick (figs. 3,4). The diamicton on the unnamed ridge is about $0.6 \mathrm{~km}$ long, $0.3 \mathrm{~km}$ wide, and $5.5-19 \mathrm{~m}$ thick (figs. 5, 6). These widths include only the crestal portion of each ridge, because solifluction has spread the diamictons down the valley sides to adjacent valley floors (figs. 1,2).

Both diamictons are sheet deposits that unconformably overlie igneous rocks of the Tertiary AudubonAlbion stock. Seismic data obtained on the unnamed ridge (fig. 6) suggest that the contact between the 


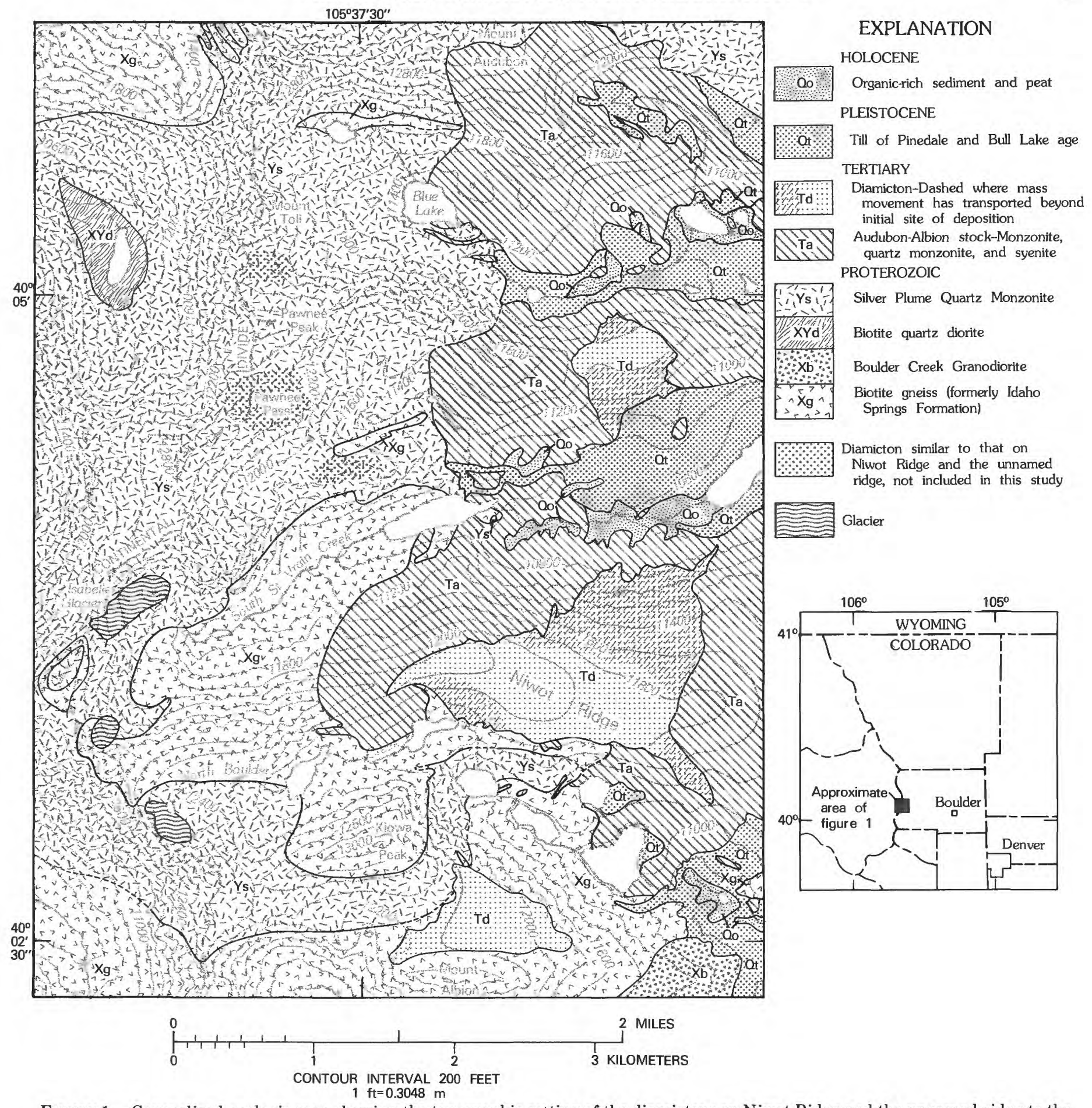

FIGURE 1.-Generalized geologic map showing the topographic setting of the diamictons on Niwot Ridge and the unnamed ridge to the north and their location on the Tertiary Audubon-Albion stock, above till in adjacent valleys, and east of two Proterozoic rock units from which most of their clasts were derived. Modified from Gable and Madole (1976); Pearson (1980). Contour interval $200 \mathrm{ft}$; 1 $\mathrm{ft}=0.3048 \mathrm{~m}$.

diamicton and bedrock is probably uneven. The upper surfaces of the diamictons are also uneven, owing to postdepositional mass movement; this is particularly apparent on Niwot Ridge, where solifluction has 


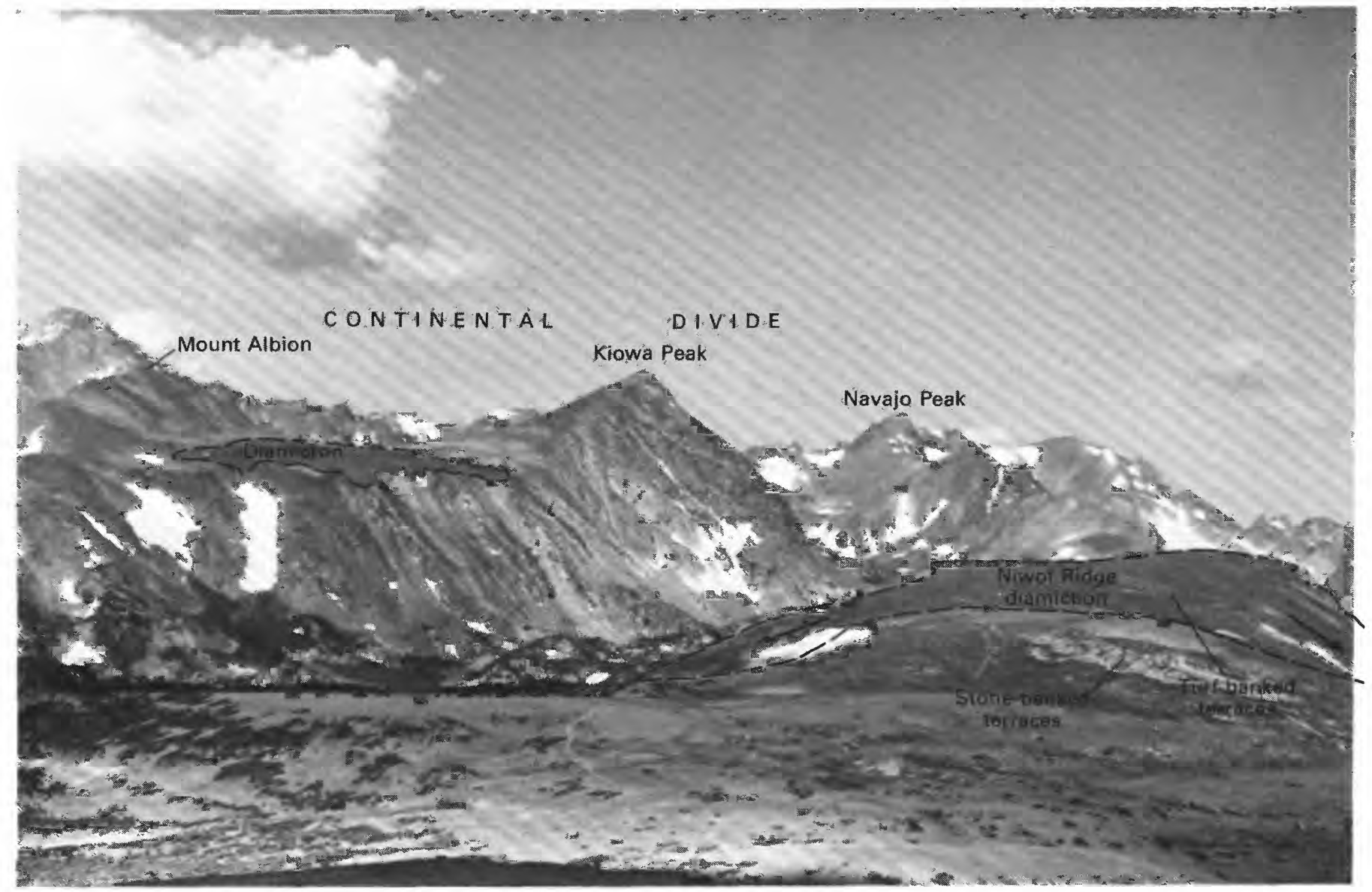

FIGURE 2.-Oblique aerial view west across the summit of Niwot Ridge to the Continental Divide. Diamictons cap ridges and fill cols at several localities along the Continental Divide in the northern Front Range. Diamicton boundaries approximate. Solifluction has transported the diamicton down the sides of Niwot Ridge across the areas now occupied by snowbanks (arrows). Turf-banked terraces and stone-banked terraces, features of periglacial mass wasting, visible on right. A diamicton similar to that on Niwot Ridge occurs in the saddle between Mount Albion and Kiowa Peak. (National Center for Atmospheric Research photo.)

formed a series of large, turf-banked terraces (faintly visible lineations from left to right in fig. 2).

Although both diamictons consist of boulders and cobbles (10-30 percent based on five measurements) in a matrix composed predominantly of sand and granules, a lenticular unit of homogeneous, well-sorted, very fine sand and silt (unit $B$, fig. 6) is present at fabric site IV on the unnamed ridge, beneath $60 \mathrm{~cm}$ of rocky colluvium. The unit was exposed throughout the extent of two trenches, each about $1 \mathrm{~m}$ deep and $3 \mathrm{~m}$ long, that were dug at right angles to each other at fabric site IV. Fine sand was encountered also in an excavation $91 \mathrm{~m}$ to the northwest. Interpretation of seismic data suggests that sediment like that in unit B also may exist at the west edge of the diamicton (fig. 6 , query), and that at the east edge of the diamicton, unit $\mathrm{B}$ ranges in thickness from 5 to $8.2 \mathrm{~m}$ and pinches out to the west.

The difference in seismic velocities between the sand of unit B and the diamictons is distinct. Eight velocities measured in unit $B$ ranged from 689 to 939 $\mathrm{m} / \mathrm{s}$ (meters per second) (mean, $\bar{x}=845$; one standard deviation, $\mathrm{s}=124) ; 15$ velocities measured in the diamicton on the unnamed ridge north of Niwot Ridge ranged from 1,015 to $2,591 \mathrm{~m} / \mathrm{s}(\overline{\mathrm{x}}=1,329 ; \mathrm{s}=313)$, and 13 velocities measured in the diamicton on Niwot Ridge ranged from 1,375 to $4,450 \mathrm{~m} / \mathrm{s}(\overline{\mathrm{x}}=3,203$; one standard deviation, $\mathrm{s}=997$ ). The higher velocities of the diamicton on Niwot Ridge could be due to frozen ground and a higher content of pebbles, cobbles, and boulders. The low end of the velocity range of both diamictons could be the result of sands like unit B being present at the sites where the low velocities were measured.

\section{COMPOSITION}

Differences in the composition of boulders and cobbles between the diamictons on Niwot Ridge and the unnamed ridge indicate that they were not derived 


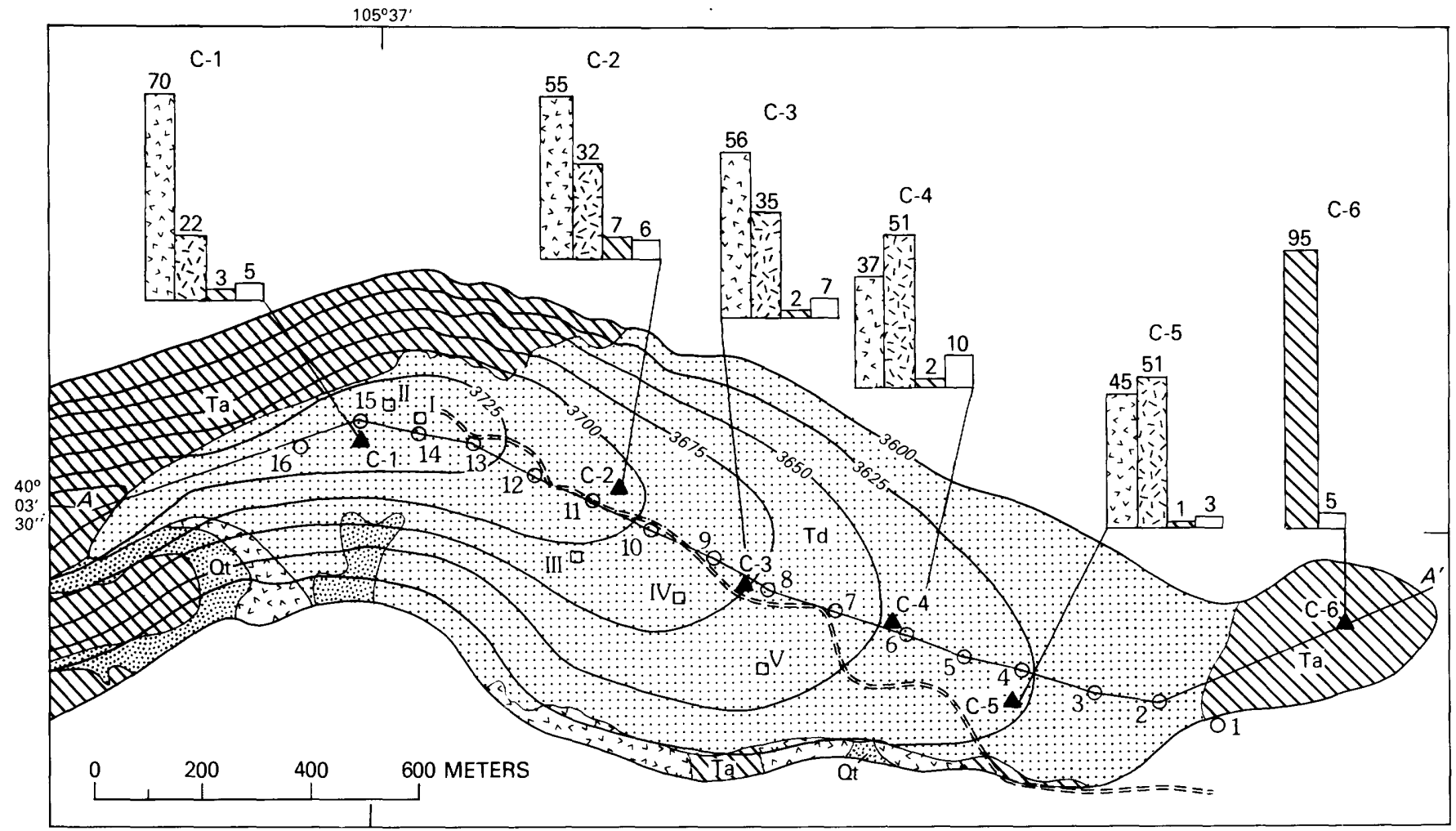

EXPLANATION

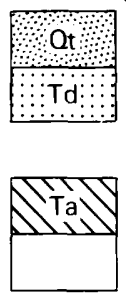

UNCONSOLIDATED DEPOSITS:

Talus deposits (Quatemary)

Diamicton (Tertiary)

BEDROCK:

Audubon-Albion stock (Tertiary)

Miscellaneous rocks chiefly from dikes and small intrusives

(Tertiary and Precambrian)

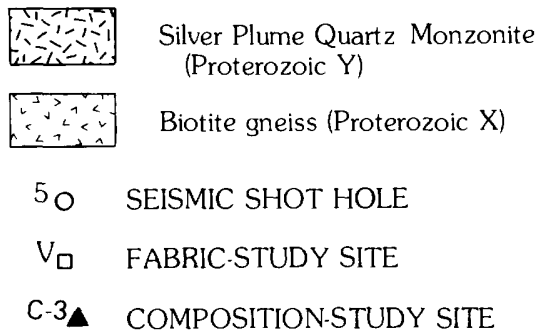

FIGURE 3.-Rock units and the diamicton on Niwot Ridge, and the composition of the diamicton and location of fabric-study pits, seismic shot holes, and composition- and boulder-study sites. Histogram columns show bedrock source, in percent, of clasts in diamicton. Section $A-A^{\prime}$, figure 4 . Contour interval $25 \mathrm{~m}$.

from the same source area, despite their location on opposite sides of upper South St. Vrain Creek. An estimate of the boulder and cobble compositions was obtained by identifying rock types within five plots (4 $\times 4 \mathrm{~m}$ ) laid out on each diamicton (figs. 4,5). Between 50 and 115 boulders and cobbles were identified in each plot; the variation in the number of clasts counted is a function of what was available on the surface. These counts indicate that $36-70$ percent of the boulders and cobbles in the diamicton on Niwot Ridge were derived from biotite gneiss (formerly called Idaho Springs Formation), 22-51 percent from the Silver Plume Quartz Monzonite("granite" clasts from migmatitic parts of the Idaho Springs Formation were counted as quartz monzonite), and 1-7 percent from the monzonite of the Audubon-Albion stock. In comparison, 66-98 percent of the boulders and cobbles in the diamicton on the unnamed ridge were derived from the Silver Plume Quartz Monzonite, 0-2 percent from biotite gneiss, and 2-34 percent from the monzonite stock.

\section{TEXTURE}

Sediment size studies concentrated on the size range and abundance of boulders, and on the percentage of sand, silt, and clay in the matrix. For the purposes of this discussion, cobbles and boulders constitute the framework clasts, and matrix includes all material less than $32 \mathrm{~mm}$ in size (pebbles, granules, sand, silt, 
TABLE 1.-Summary of boulder sizes measured in 4x4-m plots on diamictons, till, and residuum on Niwot Ridge, the unnamed ridge, and in the Red Rock-Brainard Lakes area

\begin{tabular}{|c|c|c|c|c|c|c|c|}
\hline Deposit type & Site $^{1}$ & $\begin{array}{c}\text { No. of } \\
\text { observations }\end{array}$ & $\begin{array}{l}\text { Percent } \\
25-50 \mathrm{~cm}\end{array}$ & $\begin{array}{c}\text { Percent } \\
50-75 \mathrm{~cm}\end{array}$ & $\begin{array}{c}\text { Percent } \\
75-100 \mathrm{~cm}\end{array}$ & $\begin{array}{r}\text { Percent } \\
>100 \mathrm{~cm} \\
\end{array}$ & $\begin{array}{l}\text { Maximum size } \\
\text { observed (cm) }\end{array}$ \\
\hline \multirow{7}{*}{$\begin{array}{l}\text { Diamictons on } \\
\text { Niwot Ridge } \\
\text { and the } \\
\text { unnamed } \\
\text { ridge. }\end{array}$} & NR-1 & 74 & 58 & 23 & 10 & 9 & 188 \\
\hline & NR-2 & 93 & 70 & 25 & 3 & 2 & 343 \\
\hline & NR-3 & 115 & 76 & 19 & 3 & 2 & 112 \\
\hline & NR-4 & 54 & 80 & 18 & 2 & 0 & 79 \\
\hline & NR-5 & 71 & 69 & 20 & 6 & 5 & 234 \\
\hline & UR-2 & 56 & 71 & 21 & 4 & 4 & 170 \\
\hline & UR-4 & 50 & 70 & 22 & 2 & 6 & 122 \\
\hline \multirow{3}{*}{ Till } & RB-1 & 49 & 85 & 13 & 0 & 2 & 140 \\
\hline & RB-2 & 50 & 66 & 28 & 2 & 4 & 122 \\
\hline & RB-3 & 50 & 54 & 26 & 16 & 4 & 165 \\
\hline \multirow[t]{4}{*}{ Residuum ........... } & NR-6 & 68 & 87 & 13 & 0 & 0 & 66 \\
\hline & NR-7 & 76 & 96 & 2 & 2 & 0 & 81 \\
\hline & NR-8 & 13 & 91 & 7 & 2 & 0 & 76 \\
\hline & UR-6 & 54 & 98 & 2 & 0 & 0 & 74 \\
\hline
\end{tabular}

${ }^{1}$ NR, Niwot Ridge; UR, Unnamed ridge; RB, Red Rock-Brainard Lakes area. Site locations for NR and UR are shown on figures 3 and 5 (composition-study sites), except for NR-7 and NR-8, which are too far east to be included.

and clay). As noted previously, boulders and cobbles (framework clasts) are estimated to make up 10-30 percent of the diamictons, based on five measurements. As for the matrix, eight samples from Niwot Ridge and six samples from the unnamed ridge yielded the following pairs of means, respectively: percent pebbles -49 and 28.8 ; percent granules -6.6 and 9.6; percent sand-silt-clay -43.7 and 61.6 . Sand makes up 54-76 percent of the less-than-2 $\mathrm{mm}$ fraction, whereas clay constitutes only $3.5-10.5$ percent.

\section{BOULDER-SIZE RANGE AND ABUNDANCE}

One of the most distinctive features of the diamictons is that large boulders, such as shown in figure 7, are scattered over the surface of the deposit. Large boulders are also common on the surface of the tills of the region, to such an extent that this characteristic is a criterion used in delineating till boundaries. Large boulders also occur on other surficial deposits but are not apparently as numerous and uniformly distributed. Because of these occurrences, an effort was made to quantify the similarities and differences in size and distribution of boulders on the surface of the diamictons on Niwot Ridge and the unnamed ridge, on till in nearby valleys, and on residuum on slopes and interfluves comparable to those occupied by the diamictons.

An estimate of the size and distribution of boulders in the diamictons was obtained by (1) measuring the

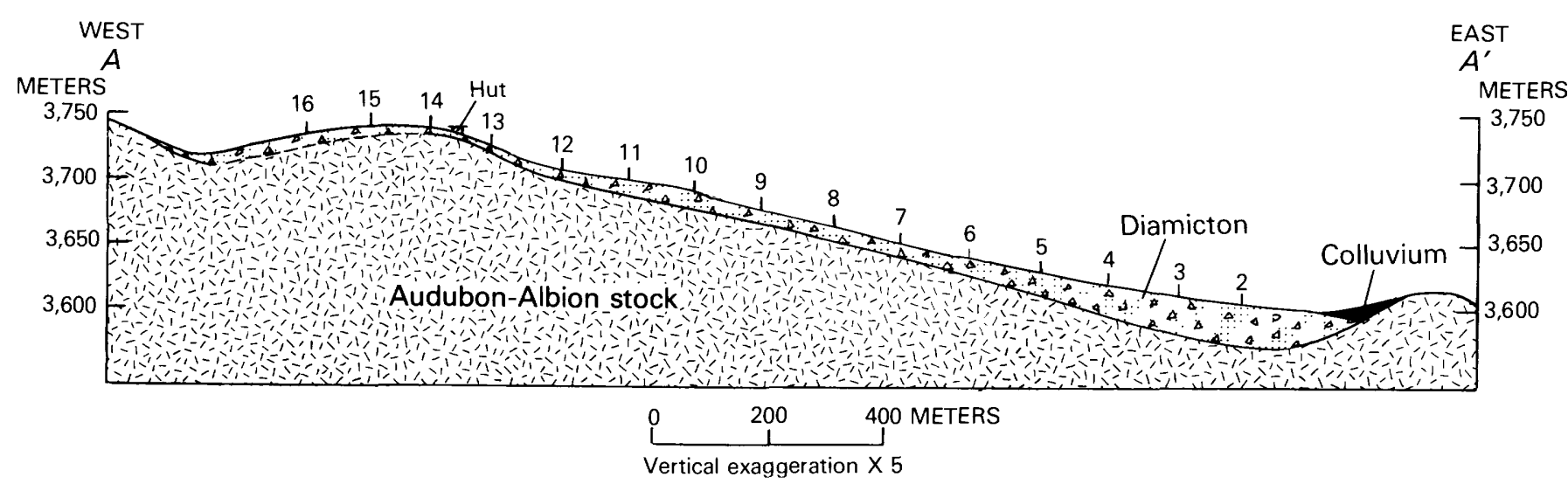

FIGURE 4.-Diagram showing the approximate thickness of the diamicton on Niwot Ridge, as interpreted from seismic data. Numbers indicate seismic shot holes (fig. 3). The diamicton ranges in thickness from a minimum of $3 \mathrm{~m}$, just west of the hut, to a maximum of $36 \mathrm{~m}$, at or just west of shot hole 2, near the eastern limit of the deposit. Spurious data recorded at six shot holes $(4,6,8,9,13$, and 15$)$ were attributed to discontinuous frozen ground. The east end of the section was oriented to connect shot hole 2 with $\mathrm{C}-6$; hence, shot hole 1 is not included in this diagram (fig. 3, orientation $A-A^{\prime}$ ). 


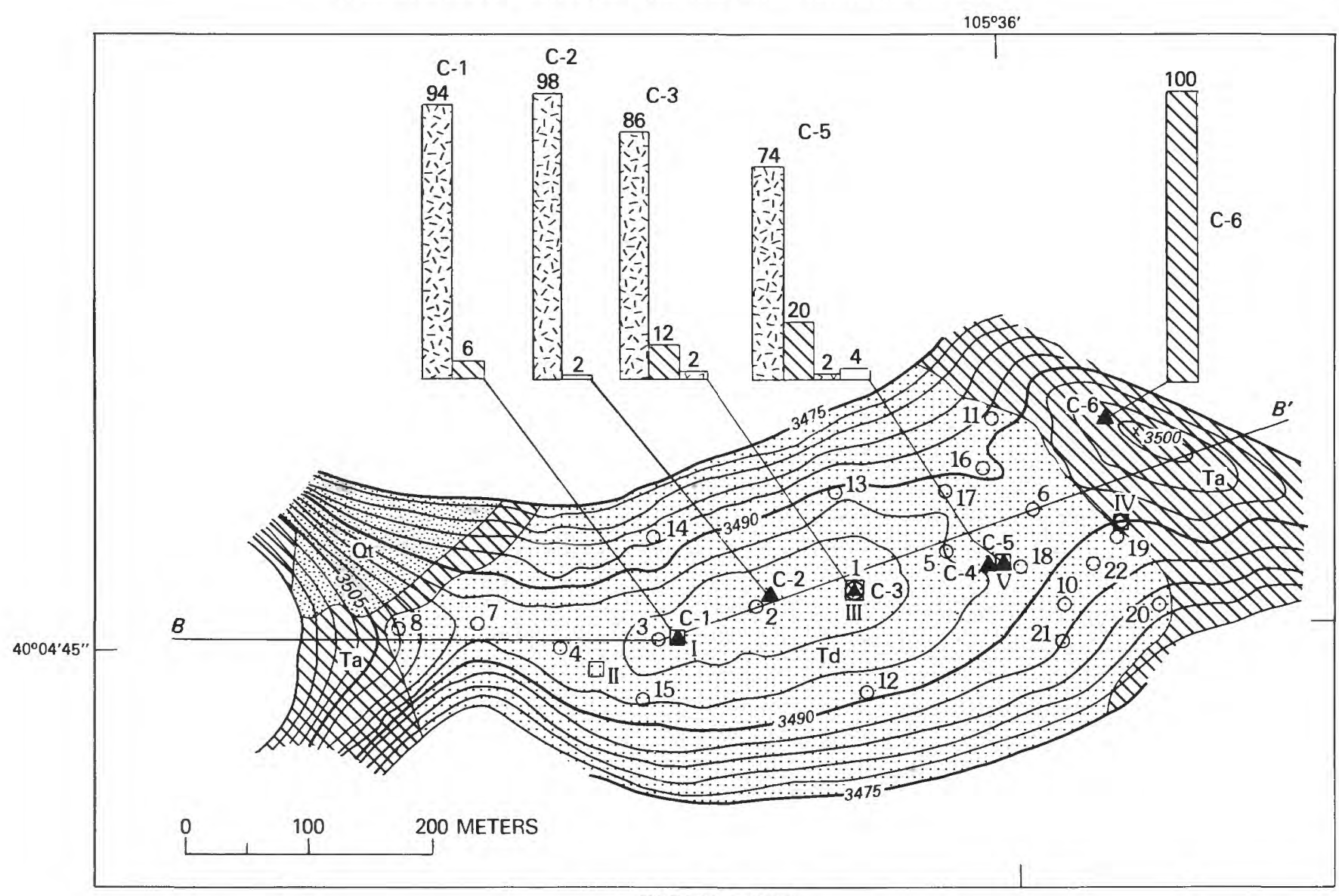

EXPLANATION

UNCONSOLIDATED DEPOSITS:

Talus deposit (Quaternary)
Diamicton (Tertiary)
BEDROCK:
$\begin{aligned} & \text { Mudubon-Albion stock (Tertiary) } \\ & \text { Mikes and small intrusives } \\ & \text { (Tertiary and Precambrian) }\end{aligned}$

Silver Plume Quartz Monzonite
(Proterozoic Y)

FIGURE 5.-Rock units and the diamicton on the unnamed ridge north of Niwot Ridge, and the composition of the diamicton and location of fabric-study pits, seismic shot holes, and composition- and boulder-study sites. Histogram columns show bedrock source, in percent, of clasts in diamicton. Section $B-B^{\prime}$, figure 6. Topography mapped with theodolite August 1968 by R. F. Madole and J. A. Clark. Contour interval $3 \mathrm{~m}$.

long axis of all boulders found on the surface within the $4 \times 4-m$ composition-study sites, and (2) measuring the long axis of all boulders longer than $75 \mathrm{~cm}$ encountered along a series of 10 randomly oriented 15 -m strips. Only a single axis (the longest exposed) was measured because most boulders are partially buried, and it is environmentally undesirable to tear up alpine tundra to measure them. The principal objective was an estimate of maximum size, and the shapes of the boulders in this area do not vary greatly, most being blocky and rectangular.
Method 1 revealed that most boulders are in the 25 to $50-\mathrm{cm}$ range regardless of deposit origin and that boulders more than $75 \mathrm{~cm}$ long are generally uncommon (table 1). Because of these results, attention was shifted to the uncommonly large boulders, those whose apparent longest axis exceeded $75 \mathrm{~cm}$. Method 2 was developed to deal only with characterizing the distribution of large boulders (fig. 8). This method was simpler than method 1 and permitted the sampling of a much larger area of each deposit in a fast and random manner. 


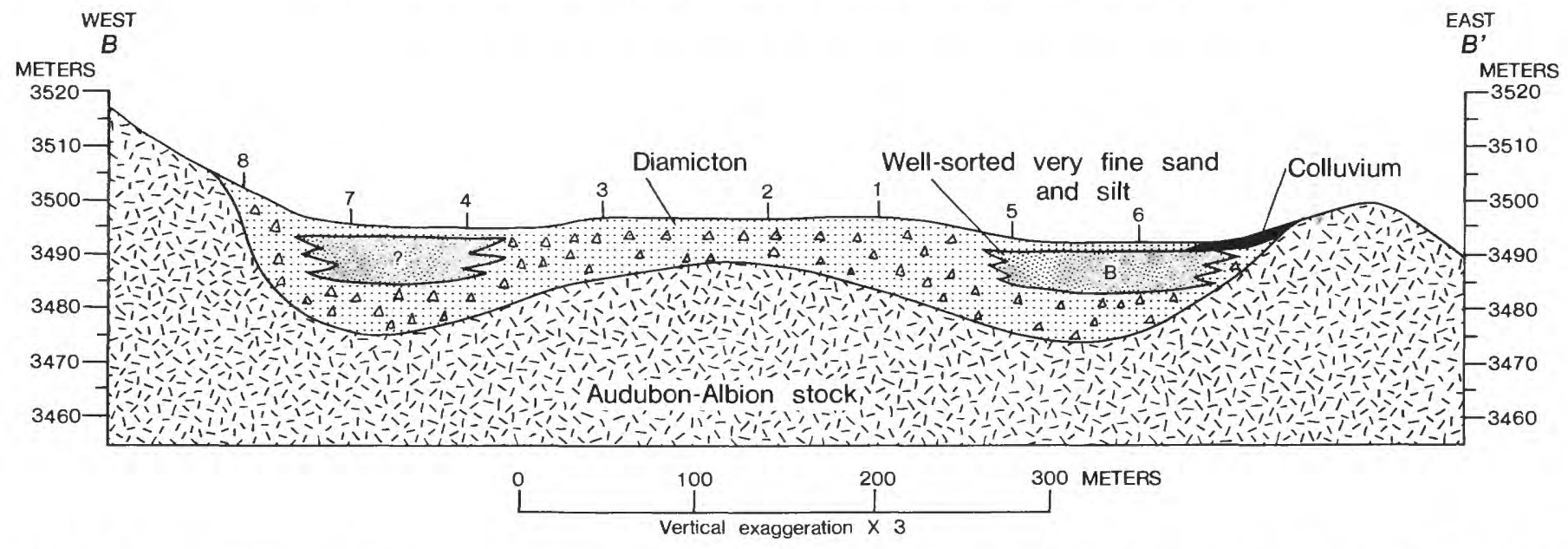

FIGURE 6.-Diagram showing the approximate thickness of the diamicton on the unnamed ridge, as interpreted from seismic data. Numbers indicate seismic shot holes (fig. 5). The diamicton is about 5.5-19 m thick. Interpretation of seismic data in section $B-B^{\prime}$ (fig. 5, orientation) suggests that the bedrock surface beneath the diamicton is irregular and that channel deposits exist near its edges. The channel(?) deposit shown on the west is inferred from the similarity of seismic velocities to those recorded for unit B, where excavations provided lithologic information.

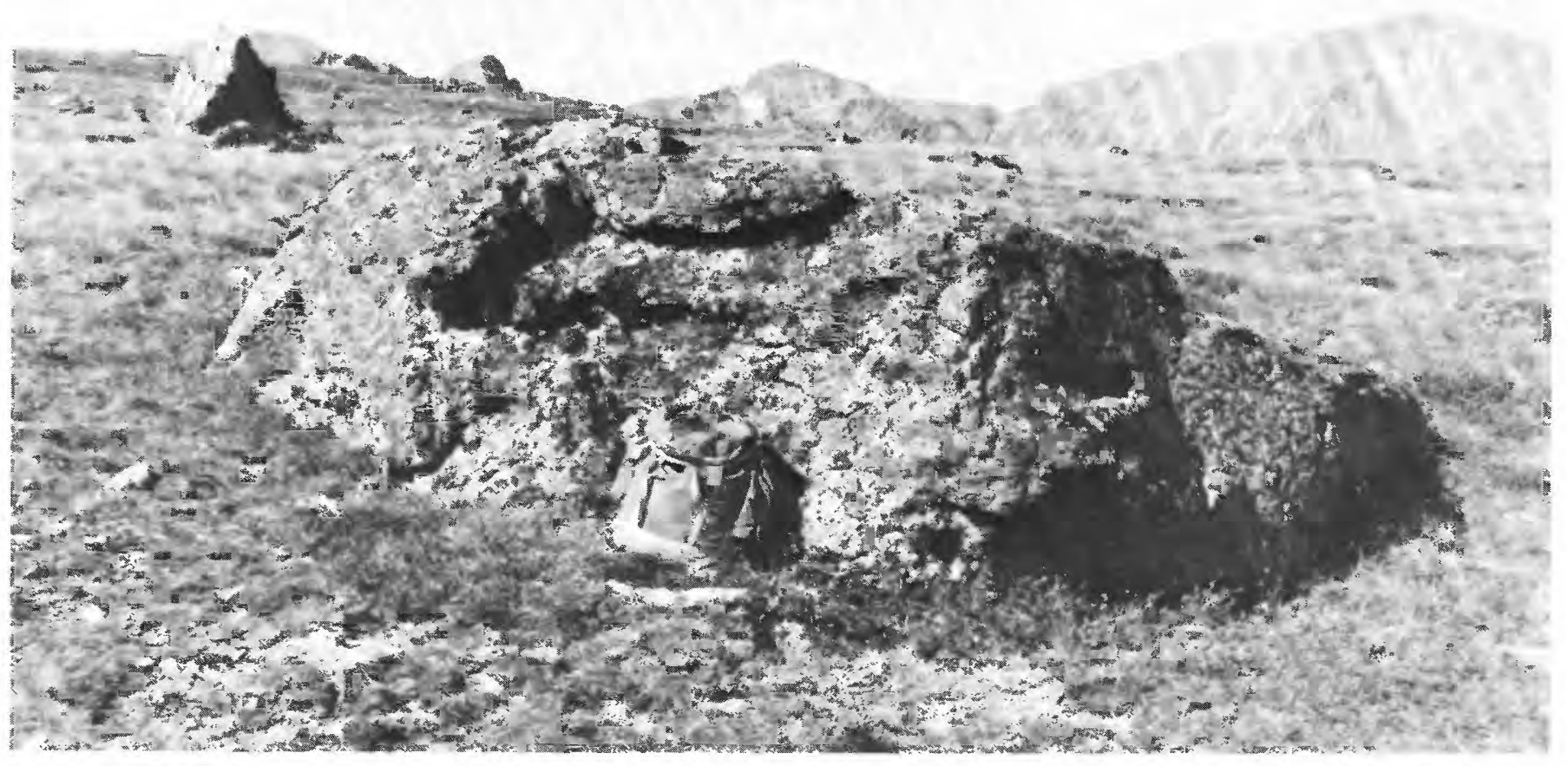

FIGURE 7.-Ground view of the diamicton on Niwot Ridge showing large boulders dispersed over its surface. Large boulders are common on the surface of the diamictons, especially on Niwot Ridge where many like the one in foreground are $3 \mathrm{~m}$ long (pack measures $40 \mathrm{x} 40 \mathrm{~cm}$ ). Most of the very large boulders, including one in foregound, are Proterozoic biotite gneiss. 


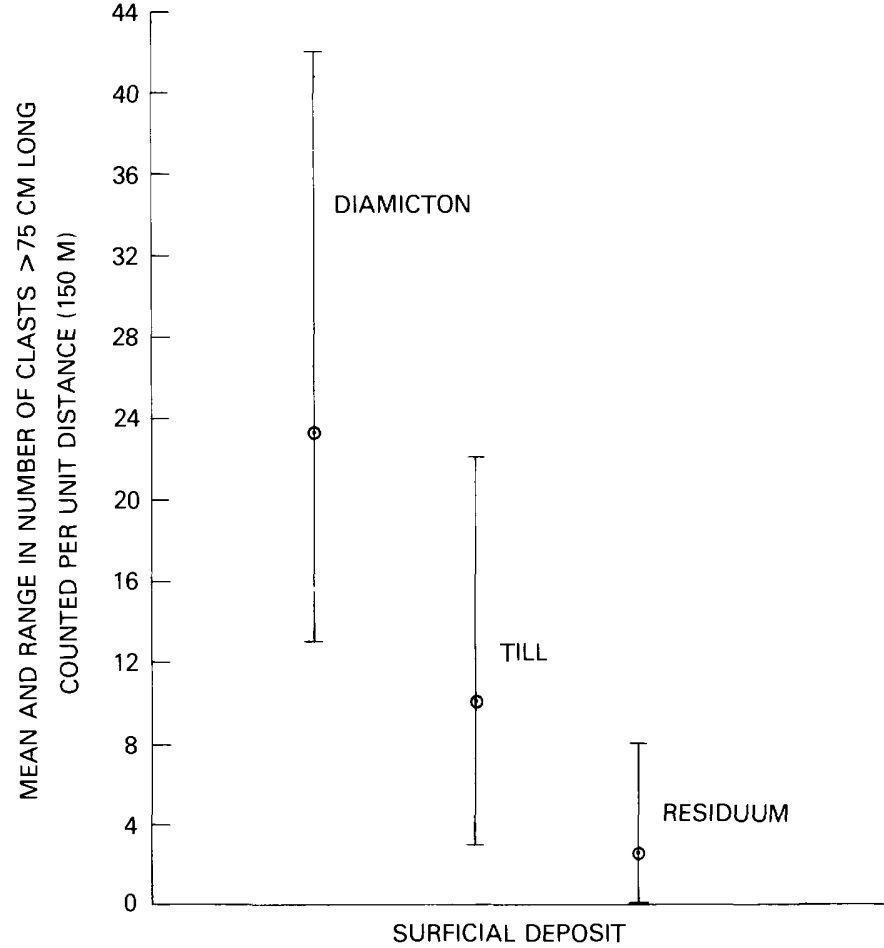

Figure 8.-Boulder abundance measured by method 2 on the diamictons on Niwot Ridge and the unnamed ridge, till of Pinedale age, and residuum. Dot indicates the mean number of boulders greater than $75 \mathrm{~cm}$ long counted per unit distance $(150$ $\mathrm{m}$ ); vertical bar indicates range in number of boulders counted.
Method 1 suggests that the diamictons on Niwot Ridge and the unnamed ridge contain a greater range of boulder sizes and larger boulders than does residuum elsewhere on these ridges and in comparable settings on other ridges. Boulders $2-4 \mathrm{~m}$ long are common in the diamictons and in the tills in the valleys below, but they are rare in the nonglacial deposits in and near the study area except along cliffs, near tors, or on moderate to steep slopes $\left(10^{\circ}-20^{\circ}\right.$ or more $)$ at altitudes above $3,600 \mathrm{~m}$. This difference in boulder size is corroborated by the frequencies obtained with method 2 (fig. 8). The number of boulders counted along each set of 10 randomly oriented 15 -m strips on the diamictons ranged from 13 to 42 , whereas the number for more than half the counts made on residuum was 0 or 1 .

\section{GRAIN-SIZE DISTRIBUTION OF THE MATRIX}

Figure 9 shows the grain-size distributions for the matrix of the diamictons and unit $B$ on the unnamed ridge north of Niwot Ridge (fig. 6). The less-than-2 $\mathrm{mm}$ fraction of the diamictons is chiefly sand (typically between 50 and 76 percent), of which the coarse and very coarse sand sizes are dominant. Clay-sized material typically makes up 3-11 percent of the lessthan-2 $\mathrm{mm}$ fraction of the diamictons. Several tens of

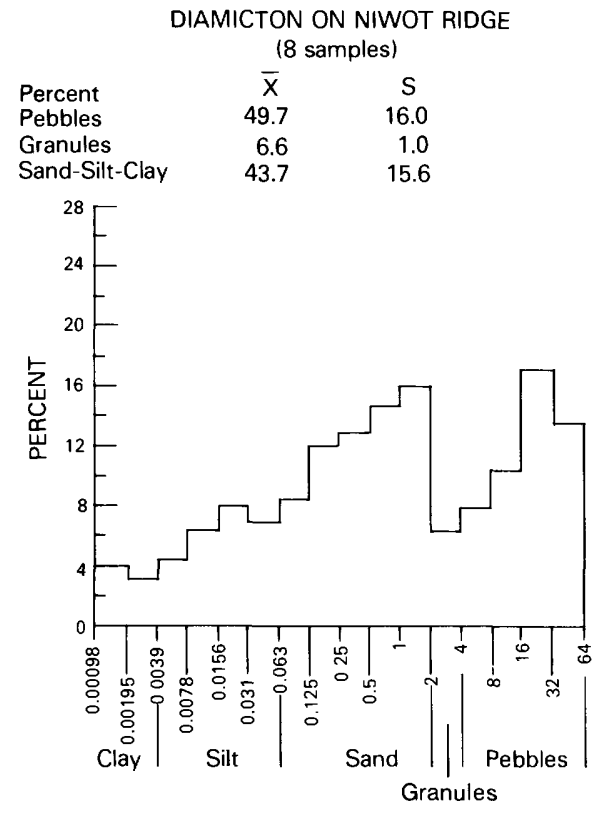

GRAIN SIZE, IN MILLIMETERS
DIAMICTON ON UNNAMED RIDGE
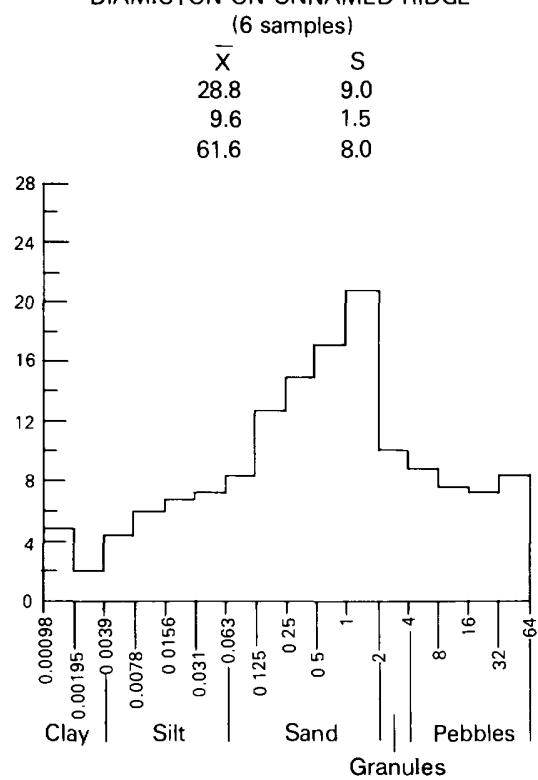

GRAIN SIZE, IN MILLIMETERS
UNIT B ON UNNAMED RIDGE (2 samples)

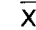

0.4

0.3
99.3

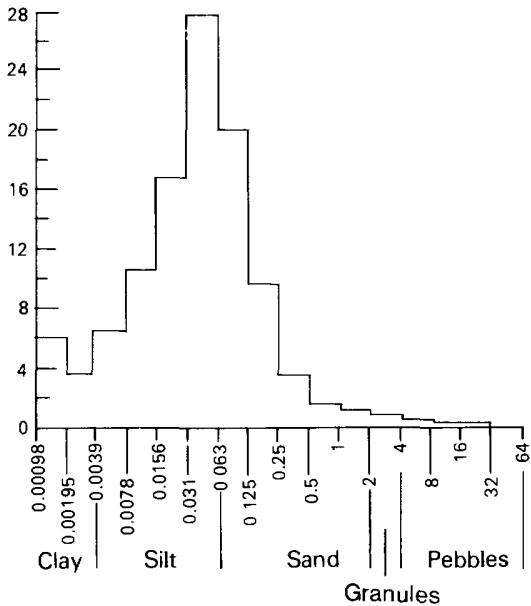

GRAIN SIZE, IN MILLIMETERS

FIGURE 9.-Diagrams showing mean grain-size distribution of samples of the Cox horizon of soil profiles at eight sites on the diamicton on Niwot Ridge, six sites on the diamicton on the unnamed ridge, and two sites on unit B on the unnamed ridge. Percent of pebbles (4-64 mm), granules (2-4 $\mathrm{mm}$ ), and sand-silt-clay (less than $2 \mathrm{~mm}$ ) is shown in terms of sample mean $(\overline{\mathrm{x}})$ and one standard deviation (s) about the mean. 
analyses show that the tills of the area (both Bull Lake and Pinedale equivalents) contain similar amounts of sand. Sand was also the dominant size in a few analyses of residuum. Hence, the grain-size distribution of the less-than- $2 \mathrm{~mm}$ fraction is believed to be controlled more by the source rocks than by the age or origin of the deposit, except for unit B.

\section{CLAST SHAPE}

Boulder shape proved to be the least significant parameter examined. It apparently reflects the number and orientation of joint sets in a particular rock type. The rocks of the study area, especially the Silver Plume Quartz Monzonite, yield mostly blocky or rectangular boulders, a fact that complicated the measurement of the macrofabrics, discussed later.

Clast roundness was measured from photographs taken of exposures of till, outwash, residuum, and diamictons. Photograph sites for residuum included localities where most clasts are from just one of the major rock types of the area (namely biotite gneiss, Proterozoic quartz monzonite, or rocks of the Tertiary stock). Tracings were made of the outlines of the clasts visible in each photograph. Next, these tracings were matched as nearly as possible to one of the categories in Lees' (1964) chart for rapid visual determination of grain angularity. Eight different observers performed the matching procedure on all the samples. The curves of figure 10 are based on a plot of all roundness values obtained by these observers for cobbles and boulders in till, outwash, residuum, and diamictons.

The diamictons on Niwot Ridge and the unnamed ridge to the north probably were derived from different source areas (see fig. 1 and discussion of composition), and because they occur at different heights, they possibly were derived at different times. In spite of these differences, the clasts of the two diamictons show a similar degree of rounding. Actually, few clasts in either deposit are well rounded. The majority are

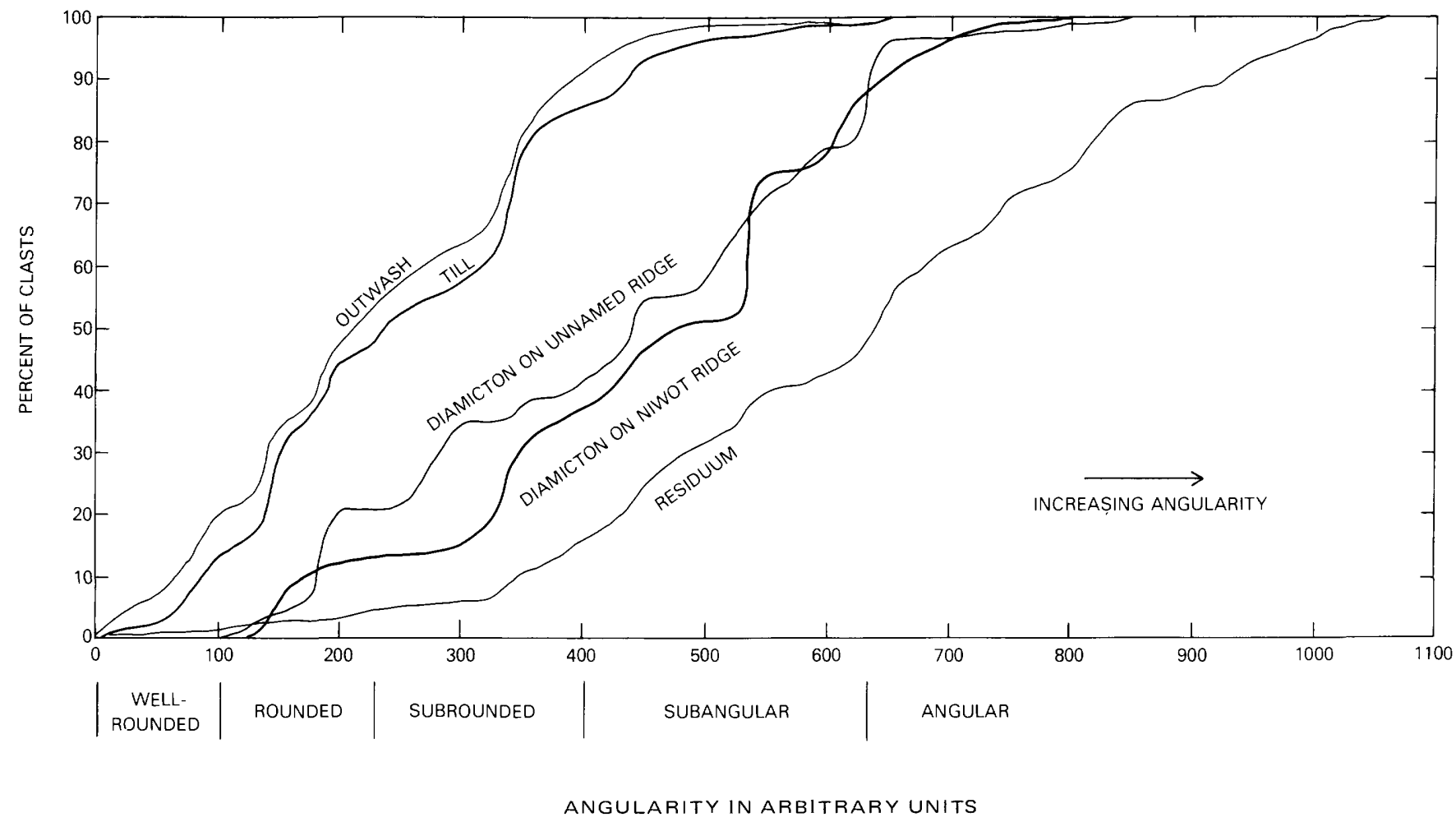

FIGURE 10.-Diagram comparing the angularity of megaclasts in till and outwash of Pinedale age, in the diamictons, and in residuum. Numerical values for angularity are from Lees (1964), and the correspondence to categories ranging from well rounded to angular is based on a comparison with Pettijohn (1949, p. 52). Cumulative frequency curves illustrate the pronounced difference in angularity between clasts in till and clasts in residuum. Whereas 85 percent of the clasts in till have angularity values less than about 390 (are well rounded to subrounded), 85 percent of the clasts in residuum have values greater than 390 (are subangular to angular) and reach values much higher than those in any of the other types of deposits. Moreover, half of the clasts in residuum are more angular than all but a fraction of the clasts (about 10 percent or less) in the diamictons. It should be noted that many of the samples used to construct the curves for till and outwash were at least twice as far from their probable source areas as were the samples used to construct the curves for the diamictons. 
subangular, many are subrounded, and a small percentage are highly angular. In contrast, the majority of clasts in residuum, whether or not moved by solifluction, tend to be strikingly angular regardless of the rock type.

The similarity of the curves for the diamictons is not due to similar rock types, because the rock types in each differ (figs. 3,5). The differences in angularity of clasts in the different types of deposits are interpreted as being a function of differences in the mode and distance of transport. Residuum, which has moved only short distances by creep or solifluction, contains clasts that are mostly unrounded.

\section{MACROFABRIC}

As used here, macrofabric refers to the orientation in three dimensions of the axes of pebbles, cobbles, and boulders, whereas microfabric refers to orientations in two dimensions only of particles chiefly finer than 2 $\mathrm{mm}$ measured in thin sections. The study of fabric and its directional significance in tills, gravel, and diamictons has a long history, which was summarized in Potter and Pettijohn (1977). The following principles from their summary apply to the sediment studied here: (1) particles immersed in the transporting media tend to aline themselves parallel to and dipping into the flow direction, and (2) particle shape and size as well as local geometry of the substrate can introduce variations; commonly large particles are better oriented than smaller ones and simple shapes better than complicated ones.
Although shape was recorded for each clast, azimuth and plunge were measured for only the longest axis. Clasts with equidimensional axes or long axes less than 1.5 times the intermediate axis were excluded from the study. Many clasts in both diamictons were excluded from study because of this limitation.

Table 2 summarizes the shapes recorded for 500 clasts in each diamicton. The similarity in the shapes of the clasts in both deposits is evident, as is the dominance of rectangular shapes. The macrofabrics described here were measured chiefly on rectangular clasts whose longest axis was 1.5 to 2 times longer than the intermediate axis. For a significant (but unrecorded) percentage of clasts, the intermediate and small axes do not differ greatly in size.

The computer program and techniques used in analyzing macrofabrics are those described by Andrews and Shimizu (1966), Andrews and Smith (1970), and Andrews (1971). Fabric analysis was made at five sites on each of the ridges as shown in figures 3 and 5 .

On the unnamed ridge north of Niwot Ridge, clast orientation from the surface to a depth of at least $75 \mathrm{~cm}$ closely parallels slope direction, which reflects the influence of mass movement as the dominant orienting process. Nonslope-related preferred orientations that trend northwest (fig. 11; table 3) were obtained at depths of only $75-100 \mathrm{~cm}$ along the relatively flat crest of this ridge (surface slope there is generally less than $3^{\circ}$ ). At site II (fig. 11), however, nonslope-related fabrics were not encountered above a depth of $1.4 \mathrm{~m}$, probably because of the slightly steeper slope at this location. Although the deeper fabrics are at variance

TABLE 2.-Shapes of clasts in the diamictons on Niwot Ridge and the unnamed ridge

\begin{tabular}{|c|c|c|c|c|c|c|}
\hline $\begin{array}{l}\text { Study } \\
\text { site }\end{array}$ & $\begin{array}{c}\text { No. of } \\
\text { observations }\end{array}$ & $\begin{array}{l}\text { Rectan- } \\
\text { gular }\end{array}$ & Blocky & Platy & $\begin{array}{l}\text { Discoidal and } \\
\text { (or) sheet }\end{array}$ & Triangular \\
\hline \multicolumn{7}{|c|}{ Diamicton on Niwot Ridge } \\
\hline $\mathrm{C}-1$ & 100 & 56 & 15 & 27 & 2 & 0 \\
\hline $\mathrm{C}-2$ & 100 & 76 & 0 & 23 & 0 & 1 \\
\hline $\mathrm{C}-3$ & 100 & 74 & 7 & 19 & 0 & 0 \\
\hline $\mathrm{C}-4$ & 100 & 59 & 5 & 33 & 1 & 2 \\
\hline $\mathrm{C}-5$ & 100 & 50 & 25 & 25 & 0 & 0 \\
\hline Total...... & 500 & 315 & 52 & 127 & 3 & 3 \\
\hline \multicolumn{2}{|c|}{ Percent of total...... } & 63 & 10 & 25 & 1 & 1 \\
\hline \multicolumn{7}{|c|}{ Diamicton on the unnamed ridge } \\
\hline $\mathrm{C}-1$ & 100 & 68 & 9 & 21 & 0 & 2 \\
\hline $\mathrm{C}-2$ & 100 & 70 & 8 & 20 & 0 & 2 \\
\hline $\mathrm{C}-3$ & 100 & 54 & 18 & 22 & 0 & 6 \\
\hline $\mathrm{C}-5$ & 100 & 56 & 24 & 18 & 2 & 0 \\
\hline II & 100 & 52 & 20 & 28 & 0 & 0 \\
\hline Total...... & 500 & 300 & 79 & 109 & 2 & 10 \\
\hline \multicolumn{2}{|c|}{ Percent of total...... } & 60 & 16 & 22 & 0.4 & 2 \\
\hline
\end{tabular}


TABLE 3.-Summary of macrofabric data for the diamicton on the unnamed ridge

[The deeper fabric listed for site II was measured between 140 and $165 \mathrm{~cm}$. It was not possible to obtain a deeper macrofabric at site IV, because of the lack of clasts in unit B]

\begin{tabular}{|c|c|c|c|c|c|c|c|c|c|}
\hline Site & $\begin{array}{l}\text { No. of } \\
\text { observa- } \\
\text { tions }\end{array}$ & $\begin{array}{c}\text { Resultant } \\
\text { vector }\left({ }^{\circ}\right) \\
(R V)^{1}\end{array}$ & $\begin{array}{c}\text { Preferred } \\
\text { orientation }\left(^{\circ}\right) \\
(\mathrm{PO})^{2}\end{array}$ & $\begin{array}{c}\text { Difference } \\
\text { PO-RV } \\
\left({ }^{\circ}\right)\end{array}$ & $\begin{array}{c}\text { Vector } \\
\text { magnitude } \\
\text { (percent) }^{3}\end{array}$ & $\begin{array}{l}\text { Circle of } \\
\text { confidence } \\
\left({ }^{\circ}\right)^{4}\end{array}$ & $\begin{array}{c}\text { Precision } \\
\text { parameter } \\
\mathrm{K}^{5}\end{array}$ & $\begin{array}{l}\text { Point of } \\
\text { balance } \\
\left({ }^{\circ}\right)^{6}\end{array}$ & $\begin{array}{c}\text { Mean } \\
\text { dip } \\
\left(^{\circ}\right)\end{array}$ \\
\hline \multicolumn{10}{|c|}{ Surface $(0-25 \mathrm{~cm})$} \\
\hline I & 25 & 341 & $319(7 \sigma)$ & 22 & 67 & 19.5 & 3.19 & -3 & -2.36 \\
\hline II & 50 & 13 & $13(11 \sigma)$ & 0 & 83 & 9.2 & 5.81 & -1 & -1.02 \\
\hline III & 49 & 358 & $45(7 \sigma)$ & 47 & 65 & 14.8 & $2.88^{*}$ & 0 & - \\
\hline IV & 50 & 339 & $295(7 \sigma)$ & 44 & 64 & 15.1 & $2.76^{*}$ & 14 & +9.8 \\
\hline $\mathrm{V}$ & 50 & 5 & $277(6 \sigma)$ & 88 & 55 & 18.3 & $2.20^{*}$ & 0 & -0.12 \\
\hline \multicolumn{10}{|c|}{ Deeper $(75-100 \mathrm{~cm})$} \\
\hline I & 26 & 340 & $320(7 \sigma)$ & 20 & 71 & 18.4 & 3.36 & -5 & - \\
\hline II & 51 & 356 & $327(8 \sigma)$ & 29 & 62 & 15.6 & $2.62^{*}$ & -8 & -5.92 \\
\hline III & 50 & 343 & $320(7 \sigma)$ & 23 & 59 & 16.9 & $2.41^{*}$ & -5 & -3.46 \\
\hline $\mathrm{V}$ & 50 & 354 & $302(4 \sigma)$ & 52 & 56 & 17.9 & $2.25^{*}$ & 22 & +13.9 \\
\hline \multicolumn{10}{|c|}{$\begin{array}{l}{ }^{1} \text { Mean orientation. } \\
2 \text { Preferred orientations were obtained from fabric diagrams contoured according to Kamb (1959). The contour interval is } \mathrm{E}+1 \sigma \text { where } \mathrm{E} \text { and } \sigma \text { are the mean and standard deviation of } \\
\text { number of orientation data points in a given area. Densities }>\mathrm{E}+3 \sigma \text { are believed to represent statistically significant preferred orientations. The number of complete contour intervals } \\
\text { terated in each diagram is given in parentheses. } \\
{ }^{3} \text { Vector magnitude was calculated as a decimal }<1 \text { and converted to a percentage. Higher values indicate stronger preferred orientations. } \\
{ }^{4} \text { Actually, an arc on the circle with a unit area }=1 \text {. } \\
{ }^{5} \text { A parameter of concentration of data. It refers to the center of mass of data on a circle, which is equivalent to } s \text { in linear statistics. This parameter is used here to determine whether } \\
\text { sample approximates a spherical-normal distribution, which is to say that } \mathrm{K} \geq 3 \text {. Values }<3 \text { are indicated above with an asterisk. } \mathrm{K} \text { increases as the spread in the distribution of data } \\
\text { nts (observations) about the mean vector decreases. } \\
{ }^{6} \text { Low values for point of balance indicate the lack of a preferred direction of dip. Negative numbers indicate that the total of dip values for clasts inclined in a southerly direction is } \\
\text { ater than the total of dip values for clasts inclined in a northerly direction, and vice versa for positive numbers. }\end{array}$} \\
\hline
\end{tabular}
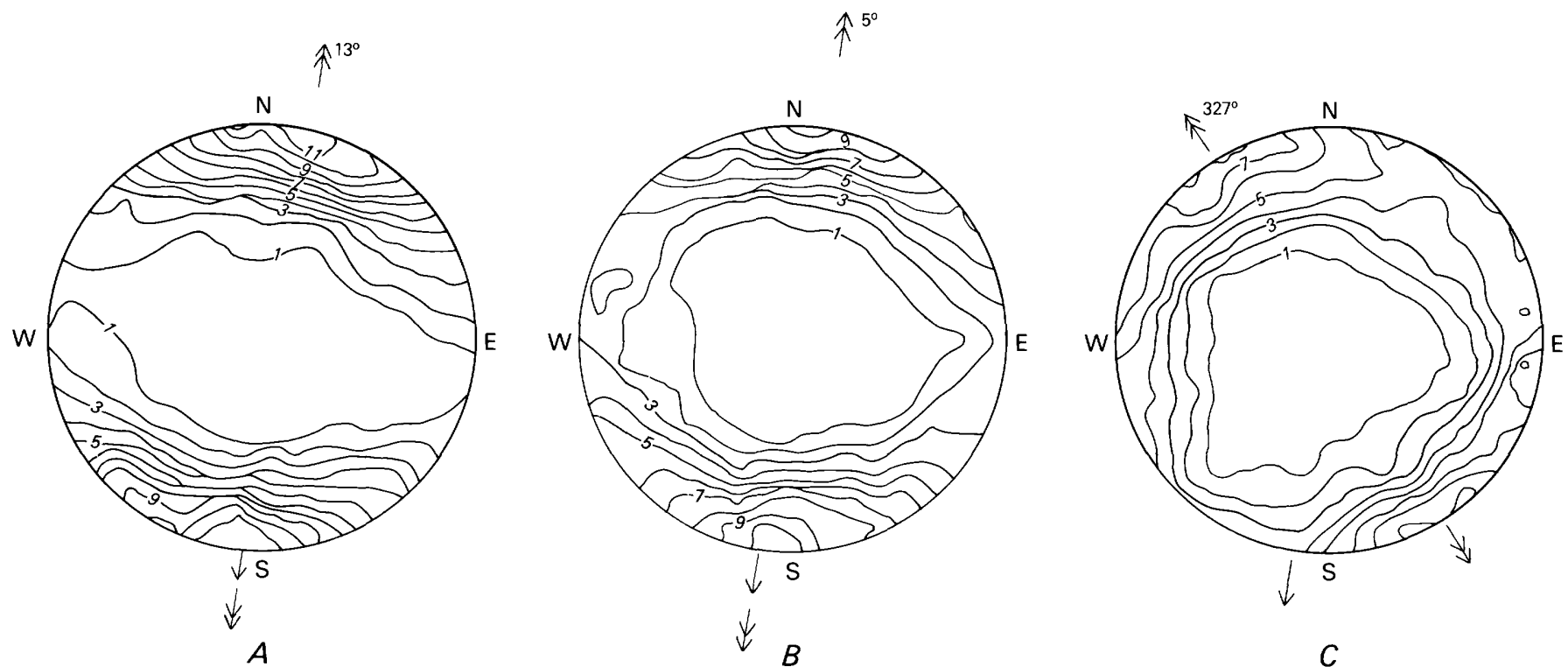

FIGURE 11.-Plot of macrofabric at site II on the unnamed ridge where slope is approximately 12 percent toward $7^{\circ}-10^{\circ}$ west of south. Single-barb arrows, slope direction; double-barbs, preferred orientation of the fabric. $A$, Fabric measured between ground surface and a depth of $25 \mathrm{~cm} ; B$, fabric measured between depths of 75 and $100 \mathrm{~cm}$; and $C$, fabric measured between depths of 140 and $150 \mathrm{~cm}$. A slope fabric (fabric whose preferred orientation is coincident with direction of slope) persists to a depth $>1 \mathrm{~m}(A, B)$. At a depth of $1.4 \mathrm{~m}(C)$, a preferred orientation appears that is at variance with existing slopes, but in agreement with the preferred orientation of the deeper fabrics of sites I, III, and V. (See table 3.) The contour interval is $1 \sigma$ (standard deviation) with respect to $\mathrm{E}$ (the mean of the number of orientation data points in a given area) (Kamb, 1959). Densities greater than $E+3 \sigma$ are believed to represent statistically significant preferred orientations. The greater the number of contours, the better developed the fabric. 
with slope directions, they generally coincide with each other and are parallel with the probable direction of transport indicated by clast composition.

The results obtained in fabric studies of the diamicton on Niwot Ridge are much less definitive than those from the diamicton on the unnamed ridge. The study sites on Niwot Ridge are 100-250 $\mathrm{m}$ higher and are located on a relict patterned ground and on solifluction terraces. These land forms suggest that freeze-thaw and mass movement have disturbed the surface of the diamicton on Niwot Ridge more than they have the surface of the diamicton on the unnamed ridge. The fabrics of all five study sites on Niwot Ridge are dominated by the effects of slow mass movement and perhaps by the sorting responsible for the patterned ground. A slope component persists in the deepest fabrics (depth of nearly $2 \mathrm{~m}$ ) even on nearly level sites (slope less than $5^{\circ}$ ). Slope component as used here refers to that peak in a multimodal circular distribution which is approximately alined with slope inclination.

Sites II and V on Niwot Ridge contained a minor nonslope-related component. Although these components point toward the cirques at the heads of South St. V rain Creek and North Boulder Creek respectively, they are too weakly developed to cite as evidence that the diamicton was transported from these localities. Sites III and IV, situated on slopes of $18^{\circ}$ and $13^{\circ}$ respectively, show nothing but pronounced slope fabrics at depths of 1.5 to $1.8 \mathrm{~m}$. Although a nonsloperelated preferred orientation was measured at a depth of $1 \mathrm{~m}$ at site I, it parallels the preferred orientation of clasts in a nearby stone polygon, and therefore is presumed to have been formed by the same processes.

\section{MICROFABRIC}

Thin sections were made of samples collected from the diamicton on the unnamed ridge at each level at each site where the macrofabric was measured. As in the macrofabric studies, the only azimuth recorded was that of the longest axis, but only fragments whose length was at least twice their width were measured. Each microfabric sample was measured twice, once with a petrographic microscope and once by projecting the $70 \times 70 \mathrm{~mm}$ thin sections with a slide projector onto grid paper where grain orientations were measured with a protractor. Use of the petrographic microscope, although more time consuming, yields somewhat better results, presumably because smaller detrital fragments and more total fragments could be measured precisely. As shown in table 4 , macrofabric and microfabric measured with the petrographic microscope compare favorably for most sites, although agreement is better at depth.

\section{SURFACE FEATURES OF QUARTZ GRAINS}

Quartz grains from the three groups of samples described in table 5 were examined with a scanning electron microscope. Fifteen quartz grains were examined from each sample. The samples were separated and cleaned according to procedures outlined by Krinsley and Takahashi (1964), procedures that were current during 1971 when this work was done. Photomicrographs were taken of grains at low magnification $(\times 50-100)$ to document variations in shape and characteristics of grain edges. Then grain surfaces were scanned at high magnifications and, if they possessed distinctive markings, were photographed.

The surface features on quartz grains from the diamictons and till (Group II and III samples) are more numerous and diverse than those on quartz grains from residuum (Group I samples). Moreover, they occur over a greater range of scale, being no less common at $\times 2,500$ to 5,000 than at $\times 250$ to 500 , the usual range for most features on grains from residuum. The markings on quartz grains from residuum are so coarse that photomicrographs at greater than $\times 500$ generally show little more than a part of the pattern focused upon.

Quartz grains from residuum tend to be more angular than quartz grains from till, and typically have very sharp edges. Many grains from till are also angular, but just as many are subangular and some are almost subrounded. None of the grains examined exhibited the roundness of the grains from littoral and eolian environments shown by Krinsley and Donahue (1968), Krinsley and Margolis (1969), and Margolis and Krinsley (1971), except one set from outwash sampled $7 \mathrm{~km}$ downstream from the lower limit of glaciation.

The principal surface feature most common in samples from residuum is the cuspate pattern (fig. $12 A, B)$. Almost as common are the arcuate steps that in places closely parallel the form of the cusps. Neither feature is restricted to a given deposit type (fig. 14A, $B$ ), but both are relatively more abundant on grains from residuum than on grains from the diamictons and till, because of the absence of other features that abound on grains from the diamictons and till.

Parallel ridge and step patterns occur on grains from all of the deposit types of table 5, but they tend to 
TABLE 4.-Comparison of mean vector and vector magnitude for the macrofabrics $(M A)$ and microfabrics $(M I)$ of the diamicton on the unnamed ridge

\begin{tabular}{|c|c|c|c|c|c|}
\hline Site & Fabric & $\begin{array}{l}\text { No. of } \\
\text { observa- } \\
\text { tions }\end{array}$ & $\begin{array}{l}\text { Vector } \\
\text { mean } \\
\left({ }^{\circ}\right)\end{array}$ & $\begin{array}{c}\text { Vector } \\
\text { magnitude } \\
\text { (percent) }\end{array}$ & $\begin{array}{l}\text { Differences between MA } \\
\text { and MI vector means } \\
\left({ }^{\circ}\right)\end{array}$ \\
\hline \multicolumn{6}{|c|}{ Depth 0-25 cm } \\
\hline 1 & $\begin{array}{c}\text { MA } \\
\text { MI }\end{array}$ & $\begin{array}{l}25 \\
85\end{array}$ & $\begin{array}{r}341 \\
10\end{array}$ & $\begin{array}{l}67 \\
59\end{array}$ & 29 \\
\hline 2 & $\begin{array}{c}\text { MA } \\
\text { MI }\end{array}$ & $\begin{array}{l}50 \\
74\end{array}$ & $\begin{array}{r}13 \\
6\end{array}$ & $\begin{array}{l}83 \\
72\end{array}$ & 7 \\
\hline 4 & $\begin{array}{l}\text { MA } \\
\text { MI }\end{array}$ & $\begin{array}{l}50 \\
80\end{array}$ & $\begin{array}{r}339 \\
15\end{array}$ & $\begin{array}{l}65 \\
61\end{array}$ & 36 \\
\hline 5 & $\begin{array}{l}\text { MA } \\
\text { MI }\end{array}$ & $\begin{array}{l}50 \\
85\end{array}$ & $\begin{array}{r}5 \\
355\end{array}$ & $\begin{array}{l}55 \\
69\end{array}$ & 10 \\
\hline \multicolumn{6}{|c|}{ Depth $95-110 \mathrm{~cm}$} \\
\hline 1 & $\begin{array}{l}\text { MA } \\
\text { MI }\end{array}$ & $\begin{array}{l}26 \\
50\end{array}$ & $\begin{array}{l}340 \\
347\end{array}$ & $\begin{array}{l}71 \\
61\end{array}$ & 7 \\
\hline 2 & $\begin{array}{c}\text { MA } \\
\text { MI }\end{array}$ & $\begin{array}{l}50 \\
60\end{array}$ & $\begin{array}{l}6 \\
4\end{array}$ & $\begin{array}{l}64 \\
61\end{array}$ & 2 \\
\hline 5 & $\begin{array}{c}\text { MA } \\
\text { MI }\end{array}$ & $\begin{array}{l}50 \\
50\end{array}$ & $\begin{array}{r}354 \\
15\end{array}$ & $\begin{array}{l}56 \\
59\end{array}$ & 21 \\
\hline & & & th $145-1$ & & \\
\hline 2 & $\begin{array}{c}\text { MA } \\
\text { MI }\end{array}$ & $\begin{array}{r}51 \\
134\end{array}$ & $\begin{array}{r}356 \\
4\end{array}$ & $\begin{array}{l}62 \\
63\end{array}$ & 8 \\
\hline
\end{tabular}

be much more abundant on grains from the diamictons and till. Also, the parallel ridges and steps on grains from the diamictons and till show much more variation in scale, step width and height, and regularity of form (fig. 13). The use of the terms step or ridge depends on the attitude of the quartz grain. In one orientation, the pattern resembles a series of vertical risers and horizontal treads; in another orientation, it resembles the dip slopes of a series of hogbacks. This pattern and the arcuate steps shown in figure 14 are so common on quartz grains from glacial environments (Krinsley and others, 1964; Krinsley and Donahue, 1968; Krinsley and Margolis, 1969; Margolis and Kennett, 1971; Coch and Krinsley, 1971; Krinsley and Doornkamp, 1973; Kennett and Brunner, 1973; Blank and Margolis, $1975)$ that they have been termed "glacial"steps (Ingersoll, 1974). However, as noted by Setlow and Karpovich (1972), Brown (1973), and Ingersoll (1974), these features are not unique to glacial deposits.

The similarity of the grain in figure $12 C$ to those in figure 14 is anomalous. The quartz grain of figure $12 C$ is from residuum, but its sample site is within $20-30 \mathrm{~m}$ of the outer limit of glacial deposits of Bull Lake age. It may therefore have been washed or blown from the nearby till. If the grain is not of glacial origin and the surface texture was formed within the residuum, the process that produced it is infrequent in residuum.

Figure $14 C$ illustrates the three dominant characteristics of surface textures of quartz grains from till, characteristics that are also dominant on grains from the diamicton on Niwot Ridge (figs. $14 A, B, D$ ). These characteristics are (1) an abundance of arcuate and parallel step or ridge patterns, (2) occurrence of surface textures at a variety of scales, and (3) surface textures in more than one orientation. Figure $14 \mathrm{~A}$ exhibits patterns of at least three different sizes, the largest of which can be easily overlooked at this magnification $(\times 5,000)$. When parallel or arcuate steps were found on grains from residuum, they were at this largest scale. At magnifications of $\times 5,000$, most grains from residuum appear to be featureless. Patterns with several ridges or steps per 1-2 $\mu \mathrm{m}$ (micrometers) were observed only on specimens from the diamictons and till. 
TABLE 5.-Surface features on quartz grains from the four types of deposits investigated with the scanning electron microscope

[All samples are from the Ward $7^{1} / 2^{\prime}$ quadrangle (Gable and Madole, 1976) and adjoining Gold Hill $7^{1} / 2^{\prime}$ quadrangle]

\begin{tabular}{|c|c|c|c|}
\hline Group & Deposit type & Sample localities & Principal surface features of quartz grains \\
\hline IA & Residuum & $\begin{array}{l}\text { Uplands underlain mostly by deeply weathered } \\
\text { crystalline rocks well below timberline and east } \\
\text { of the glacial limit where mass movement is } \\
\text { slight to moderate (figs. } 12 A-C \text { ). }\end{array}$ & $\begin{array}{l}\text { Magnifications of } \times 1,000-5,000 \text { : low relief; flat, relatively } \\
\text { featureless surfaces dominate. Magnifications of } \times 200-500 \\
\text { angular grain edges, medium relief, cuspate patterns closely } \\
\text { paralleled in places by arcuate steps, precipitated silica in } \\
\text { hollows; abundant flat featureless surfaces; crystal over } \\
\text { growths were observed in one sample. }\end{array}$ \\
\hline IB & Residuum & $\begin{array}{l}\text { Alpine settings comparable to those of the diamic- } \\
\text { tons, where mass movement by solifluction and } \\
\text { creep is moderate to great (fig. } 12 D \text { ). }\end{array}$ & $\begin{array}{l}\text { Magnifications of } \times 1,000-5,000 \text { : low relief, extensive areas of } \\
\text { extremely flat, clean, featureless surfaces dominate. Mag } \\
\text { nifications of } \times 200-500 \text { : very angular, sharp grain edges } \\
\text { medium relief, conchoidal fractures, layering (probably edges } \\
\text { of cleavage plates, Krinsley and Doornkamp, 1973), and } \\
\text { smooth surfaces are common. }\end{array}$ \\
\hline II & Diamictons & $\begin{array}{l}\text { Niwot Ridge and the unnamed ridge (figs. } 13 A \text {; } \\
\qquad 14 A, B, D ; 15 A, B \text { ). }\end{array}$ & $\begin{array}{l}\text { Magnifications of } \times 200-5,000 \text { : angular to subangular grain } \\
\text { edges, high relief, abundant arc-shaped steps and paralle } \\
\text { steps that vary widely in scale, occasional striations(?). }\end{array}$ \\
\hline III & Till & $\begin{array}{l}\text { Moraines in the upper valleys of South St. Vrain } \\
\text { Creek, North Boulder Creek, and James Creek } \\
\text { (figs. } 13 B-D, 14 C \text { ). }\end{array}$ & $\begin{array}{l}\text { Magnifications of } \times 200-5,500 \text { : angular to subangular grain } \\
\text { edges, high relief, abundant arc-shaped steps, parallel steps } \\
\text { conchoidal fractures that vary widely in size and orientation. }\end{array}$ \\
\hline
\end{tabular}

Some grains from both the diamictons and till show features that might be grooves, or striations (fig. 15). Variation in orientation of these linear features suggests origin by abrasion.

\section{POSSIBLE ORIGINS FOR THE DIAMICTONS}

The diamictons on Niwot Ridge and the unnamed ridge to the north are very poorly sorted and contain large boulders of exotic rock types in a fine-grained matrix. Stratification, if present, is so crude that it is not visible in small exposures (1-2 $\mathrm{m}$ across). These characteristics are evident in four categories of deposits, all of which are common to this region: (1) periglacial mass wasting deposits produced by cryoturbation, solifluction, and creep; (2) landslide deposits produced primarily by flow as in rockfall or rockslide avalanches and debris flows; (3) glacial deposits; and (4) alluvial-colluvial deposits, aggregations of alluvium, colluvium, and debris flow deposits in variable amounts. In the following discussion, the origin of the diamictons on Niwot Ridge and the unnamed ridge will be examined in terms of these four types of deposits.

\section{PERIGLACIAL MASS WASTING DEPOSITS}

The study area abounds with features produced by cryoturbation, frost creep, and solifluction. These features, including both relict and active forms, are particularly abundant on Niwot Ridge (figs. 2, 16), where they have been described in detail by Benedict (1970). Hence, transport by the combined action of periglacial processes was considered as a possible origin for the diamictons. This origin, however, proved to be untenable, and the features so produced are regarded simply as an overprint on deposits that were already there.

The occurrence of sediment containing abundant clasts mainly of Proterozoic rocks on a monzonite stock of Tertiary age is difficult to explain in this case by downslope transport by creep and solifluction, because the nearest summits are composed of the Tertiary monzonite. Monzonite rock rubble mantles the ridges west of both diamictons for distances of $0.5 \mathrm{~km}$ and more (fig. 16); yet, few clasts of monzonite are evident in either diamicton. The preponderance of Proterozoic Y Silver Plume Quartz Monzonite in the diamicton on the unnamed ridge indicates that the source of this sediment lay beyond the limits of the monzonite stock, $1-3 \mathrm{~km}$ to the northwest (fig. 1). Selective transport of exotic clasts from a distant source in preference to those from the nearest summits is inconsistent with an origin by slow mass movement.

Fabric data also suggest that an origin by creep and solifluction is not reasonable. Macrofabric study at four sites on the diamicton on the unnamed ridge (figs. 5,11 ; table 2) shows that clasts have long axes with a northwest-southeast preferred orientation. This does not conform to existing slope directions (figs. 1,5 ) but 

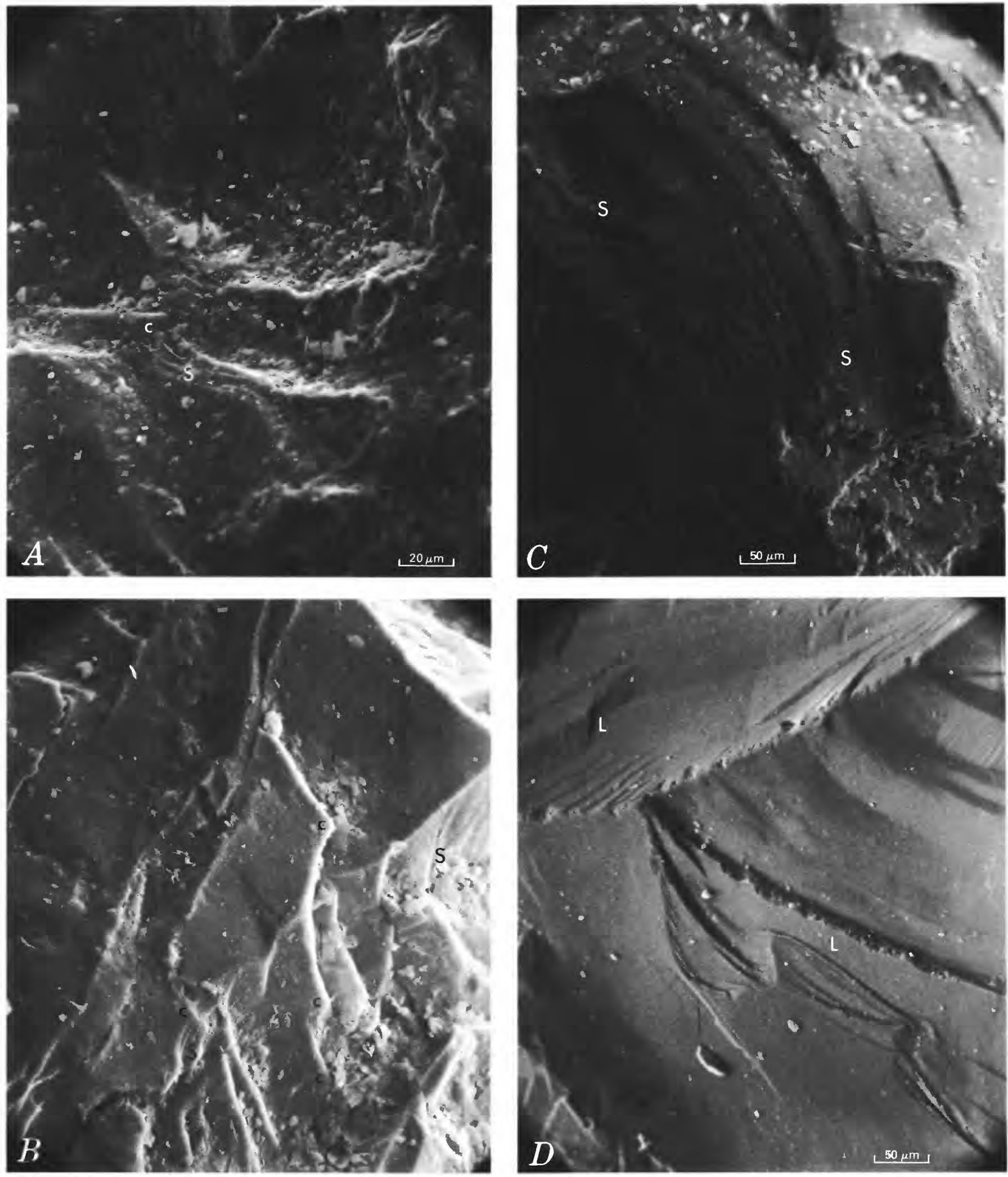

FIGURE 12.-Scanning electron micrographs showing quartz-grain surface textures typical of Group I samples. $A, B$, Grains from residuum just below the limit of till, Brainard Lake Road, South St. Vrain drainage basin. C, Grain from residuum derived from Silver Plume Quartz Monzonite at junction of Brainard Lake Road and Colorado Highway 119. D, Grain from residuum at composition-study site C-6 on Niwot Ridge (fig. 3). Grains from residuum are angular and typically have sharp edges. The most common surface features are cuspate patterns (c) and arcuate steps $(\mathrm{S})$, both of which are probably caused by conchoidal fracturing. Layers $(\mathrm{L})$, both fine and coarse, are probably the edges of cleavage plates, as defined by Krinsley and Doornkamp (1973, p. 8). 

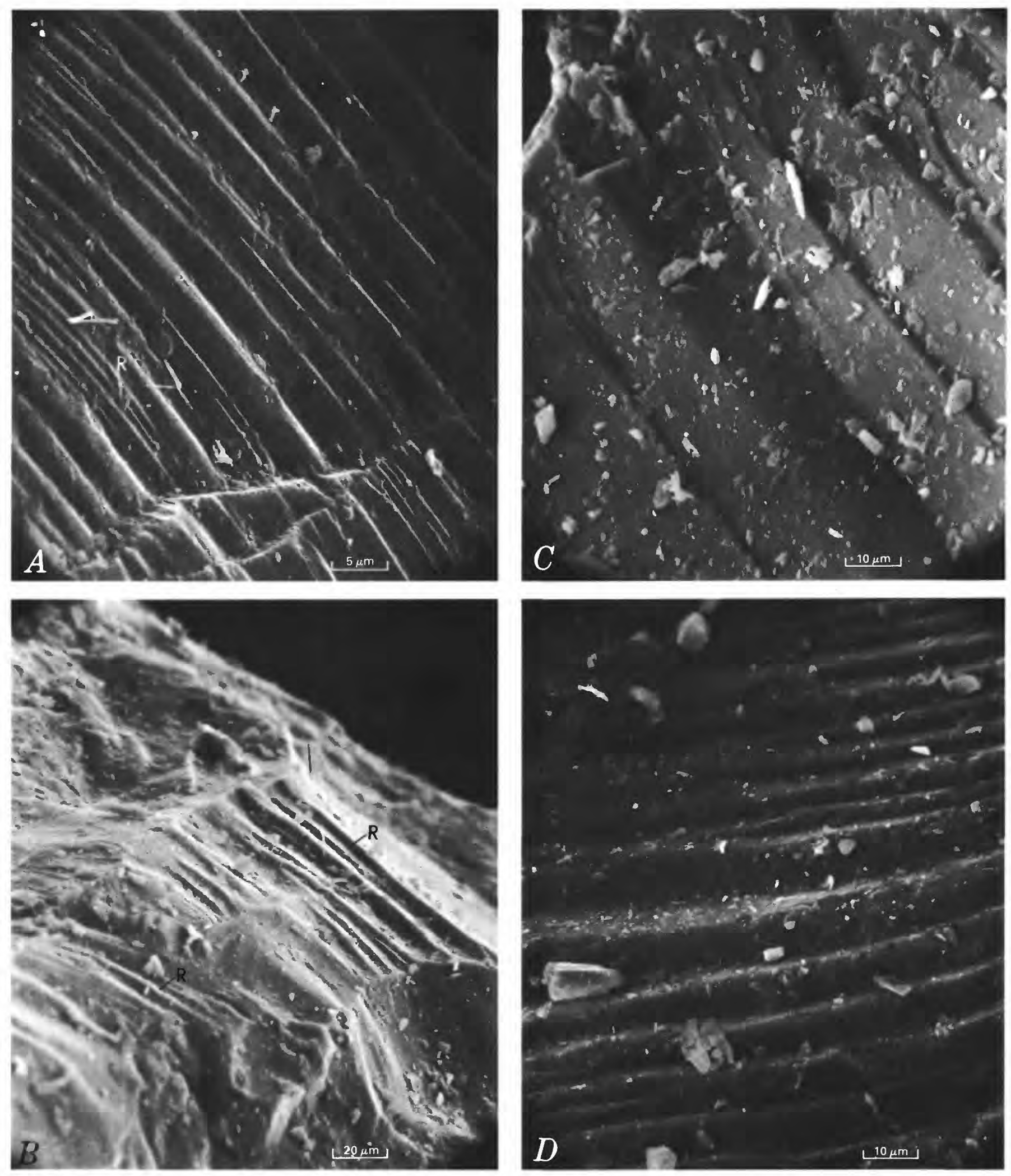

FIGURE 13.-Scanning electron micrographs showing parallel ridge and step patterns. Whether or not of the same origin, these patterns are more common on grains from sample groups II and III than on grains from residuum. $A$. Grain from the diamicton on Niwot Ridge. $B$, $C, D$, Grains from till collected $8 \mathrm{~m}$ below moraine surface in an excavation about $0.6 \mathrm{~km}$ east of Silver Lake, near North Boulder Creek. Sharp, parallel ridges (R) occur frequently on grain surfaces or sides. These probably represent the trace or upturned edges of cleavage plates (Krinsley and Doornkamp, 1973). 

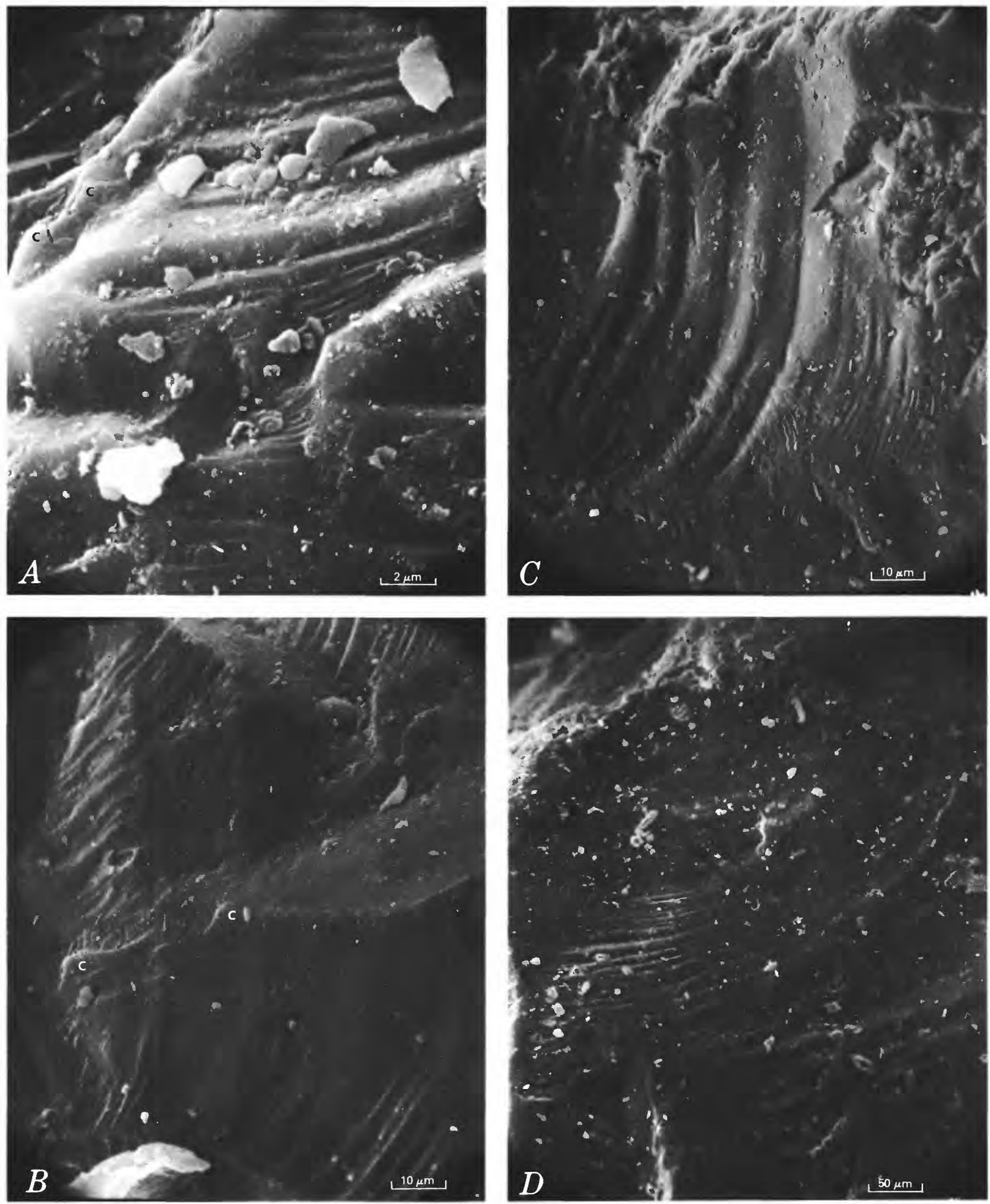

FIGURE 14.-Scanning electron micrographs. $A, B, C$, Grains from the diamicton on Niwot Ridge; c, cuspate pattern. $D$, Grain from till collected $8 \mathrm{~m}$ below moraine surface in an excavation about $0.6 \mathrm{~km}$ east of Silver Lake, North Boulder Creek drainage basin. All of these grains are similar in that they contain an abundance of arcuate, parallel step or ridge patterns of different sizes and orientations. 

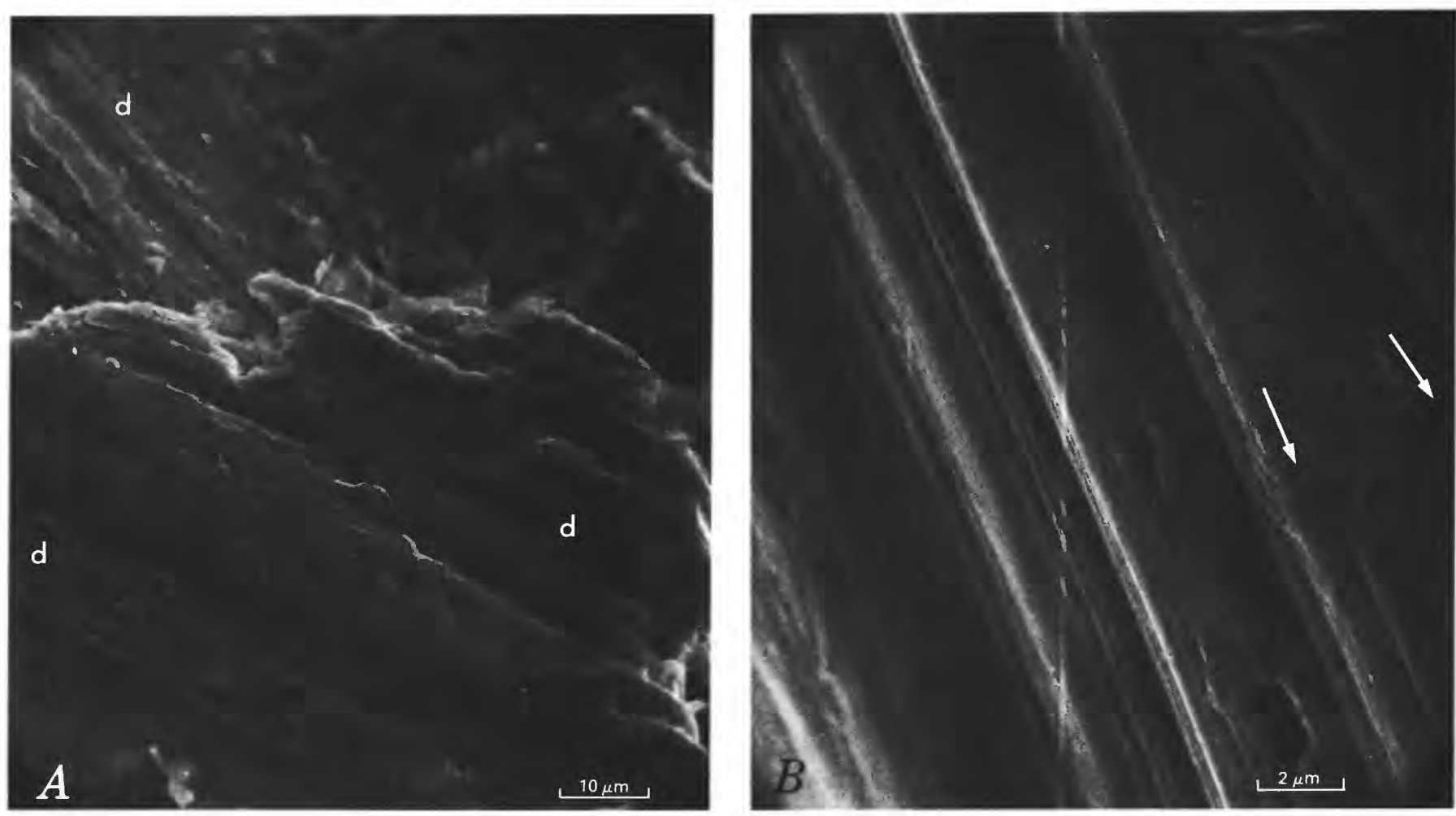

FIGURE 15.-Scanning electron micrographs of two grains from the diamicton on Niwot Ridge showing linear depressions. $A$, Depressions (d) are probably part of the pattern created by upturned cleavage plates (ridges). $B$, Variations in the orientation of linear grooves (denoted by arrows and not to be confused with the scanning artifacts perpendicular to the top and bottom of view) suggest the possibility of origin by abrasion.

does corroborate evidence provided by the composition of the deposit, which indicates that the deposit was transported from an area to the northwest. Sites II and $\mathrm{V}$ on Niwot Ridge also possess nonslope-related components, although much less strongly developed. Their significance, however, is open to question because of the degree to which postdepositional mass movement has disturbed the deposit on Niwot Ridge.

As shown in figure 8 and table 1 , the diamictons on Niwot Ridge and the unnamed ridge have many more boulders than do other surficial deposits in the area located at comparable altitudes. Boulder counts made on residuum, most of which is undergoing slow mass movement, show that (1) boulders longer than $75 \mathrm{~cm}$ are rare except around rock knobs and (2) boulder size does not vary significantly between the different rock types of the area. The large $(2-3 \mathrm{~m})$ boulders in the diamictons (fig. 7) are mainly Proterozoic biotite gneiss, and to a lesser extent, Proterozoic quartz monzonite; yet, residuum formed from these same rock types on eastern Niwot Ridge does not contain numerous large boulders. The rapid decline in numbers of large boulders away from the few rock knobs that crop out along the ridge suggests that large boulders do not move far from their source on slopes of less than $15^{\circ}$. Therefore, I suggest that the large boulders in the diamictons on Niwot Ridge and the unnamed ridge to the north accumulated at the base of peaks and steep valley sides near the Continental Divide, and later were transported to their present locations by some process other than slow mass movement.

Figure 10 shows that the clasts in the diamictons are more rounded than those in residuum even though the rock types are the same in both units. The greater rounding of the clasts in the diamicton supports the interpretation that they were transported by some means other than slow mass movement.

The fact that the diamicton on the unnamed ridge underlies and overlies a unit of very fine sand and silt along its northeast edge, unit B of figure 6 , demonstrates that the diamicton and unit $\mathrm{B}$ are contemporaneous. The shape, texture, and sorting of unit B seem inexplicable by any form of slow mass movement in a periglacial environment.

\section{LANDSLIDE DEPOSITS}

Landsliding could account for the composition of the diamictons and the abundance of large boulders. 


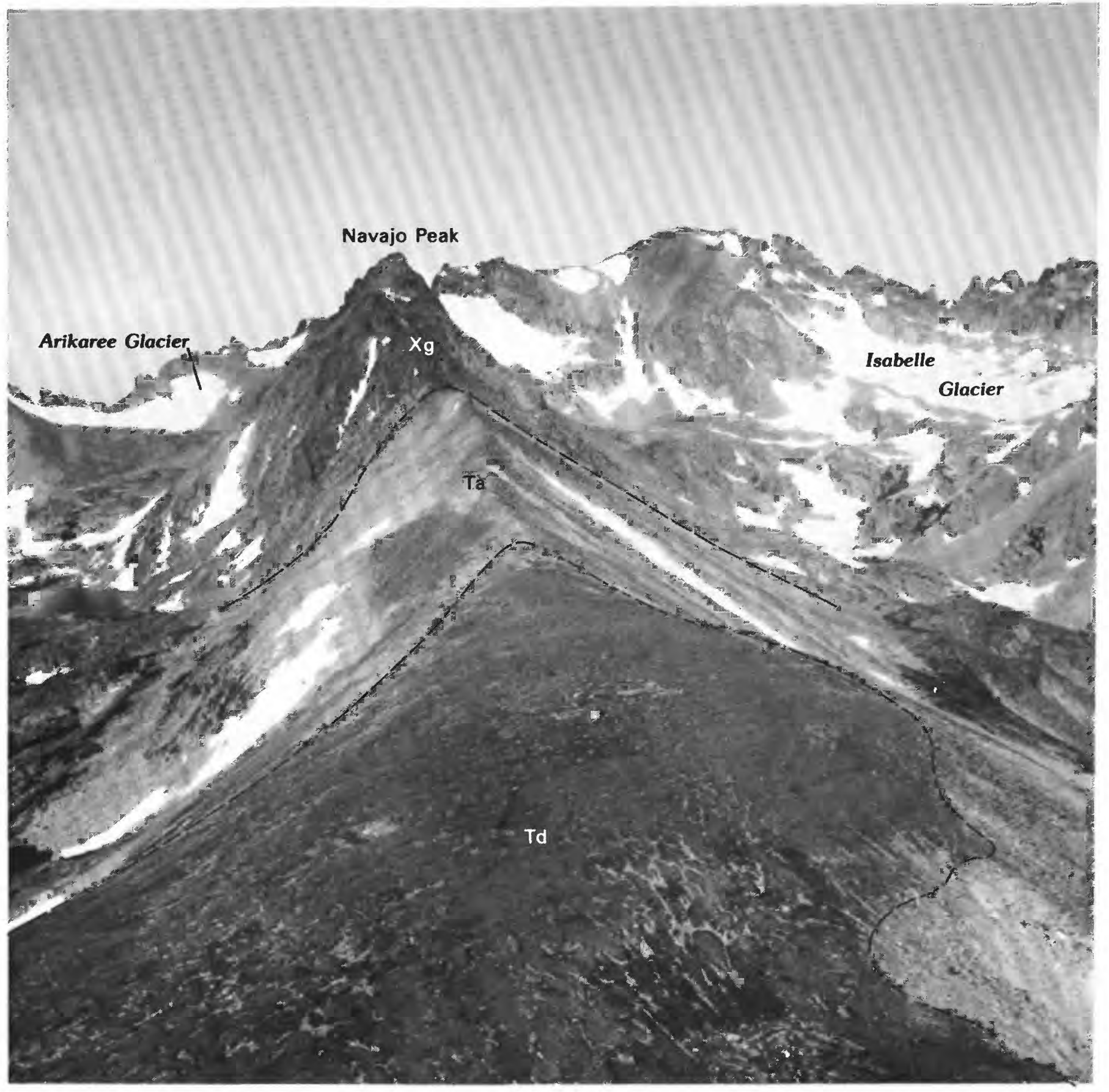

FIgURE 16.-Oblique aerial view to west showing the diamicton on Niwot Ridge(Td) overlying Tertiary monzonite (Ta). Monzonite extends for about $0.5 \mathrm{~km}$ west of the diamicton to the contact with Proterozoic biotite gneiss $(\mathrm{Xg})$. The diamicton on Niwot Ridge, although almost surrounded by rocks of the stock, contains only a small percentage of clasts from the stock. (See figs. 1, 3.) Patterned ground, noted in the discussion of macrofabrics, is visible over most of the diamicton surface. (National Center for Atmospheric Research photo.)

However, mass flow capable of moving this volume of debris for distances of $3-4 \mathrm{~km}$ over relatively low gradients is limited to rock avalanches and debris flows.

\section{ROCKFALL AND ROCKSLIDE AVALANCHES}

A theory of origin by rockfall or rockslide avalanching has several weaknesses: (1) an exceptionally 
low coefficient of friction would have been required for so long a slide on such a low gradient; (2) this type of landslide tends to produce angular brecciated material, which is not the kind of material described here; (3) this ty pe of landslide tends to occur in incompetent, layered, deformed rocks that occupy structural attitudes favorable to sliding, whereas the study area is underlain by competent, coarse crystalline, foliate to massive rocks; (4) large landslides are uncommon in this part of the Front Range; and (5) diamictons similar to those on Niwot Ridge and the unnamed ridge occur on the Continental Divide itself.

The diamicton on Niwot Ridge was at least $2 \mathrm{~km}$ long. The west end of what remains of the diamicton is only $300 \mathrm{~m}$ lower than the highest parts of the Continental Divide to the west. The vertical head and gradient requirements for moving this volume of debris $3-4 \mathrm{~km}$ horizontally eliminates most forms of "dry" landsliding except for rockfall or rockslide avalanches. A thin cushion of compressed air beneath the slide as described by Shreve (1968) for the Blackhawk, Elm, and Frank landslides would be required to account for so long a slide with so little drop. Even if the gradient were doubled by assuming that $300 \mathrm{~m}$ of relief has been lost due to erosional lowering of the slide source area, the maximum coefficient of friction (Shreve, 1968) would amount to only 0.23 , a value that would still require a cushion of compressed air to explain the slide.

Rockfall and rockslide avalanches produce breccias that are texturally different from the diamictons on Niwot Ridge and the unnamed ridge. The material in rock avalanches is shattered by fall but then undergoes little additional movement; consequently, little abrasion or rounding occurs during transport. Shreve (1968) cited a "jigsaw puzzle" effect, a condition where blocks which had shattered on impact remained undispersed during sliding, as evidence for transportation on a cushion of compressed air. Transport of this type would not account for the grain-size distributions and clast roundness observed in the diamictons, nor the unit of very fine sand and silt (unit B, fig. 6) associated with the deposit on the unnamed ridge.

All of the large landslides described by Shreve (1968) occurred in incompetent, layered rocks that had been structurally deformed and had structural attitudes favorable to sliding. Three slides involved undercut thrust blocks, two occurred on dip slopes, and one was produced by quarrying. The geologic setting of the diamictons of this paper contrasts markedly with that of these six landslides. The rocks are coarse crystalline, foliate to massive, and very competent.

Landslides are uncommon within the crystalline core of the northern Front Range except where the mineral belt, a northeast-trending Precambrian structure characterized by massive fracturing and broad shear zones (Tweto and Sims, 1963), intersects the Williams Range thrust fault and related structures on the northeast side of the thrust (Madole and others, 1974; Robinson and others, 1974). North of the mineral belt a few landslides do occur where Pleistocene glaciation oversteepened valley walls and where glacial till was plastered on very steep slopes, but these are comparatively small.

Lastly, diamictons exist in saddles on or near the Continental Divide at Pawnee Pass, between Pawnee Peak and Mount Toll, and between Kiowa Peak and Mount Albion (figs. 1,2). The physical similarity of these diamictons to those on Niwot Ridge and the unnamed ridge suggests a common origin. Two of the diamictons are on the Continental Divide itself, which, if they are due to landsliding, limits their potential source areas to a few relatively low nearby summits.

\section{DEBRIS FLOWS}

Debris flow is used here as a general term for debris that flows as a viscous fluid or slurry, a suspension of solids in a liquid. The debris may be of any size or include a broad range of sizes. Mudflows, for example, are a type of debris flow. The occurrence of large flows of the Slumgullion type (Endlich, 1876; Howe, 1909) or smaller ones like those along the east flank of the Front Range (Madole and others, 1973) require incompetent rocks that fail when undercut by erosion or are wetted excessively. At Slumgullion, hydrothermal alteration produced a weak, easily deformed unit beneath a section of massive, competent, volcanic rock. Along the east flank of the Front Range, mass failures have resulted where silty-clay residuum or weak, steeply dipping shales, some containing swelling clays, have been saturated by water from adjacent aquifers. Similar conditions are absent in the crystalline core of the Front Range where massive, resistant rocks produce coarse residuum of which 50-75 percent of the less-than-2 $\mathrm{mm}$ fraction is sand, and commonly less than 10 percent is clay. Small-scale debris flows do, however, occur commonly on talus in the heads of many Front Range valleys. Curry (1966) described flows of this type in the Tenmile Range $60 \mathrm{~km}$ southwest of Niwot Ridge.

The numerous large boulders on the diamictons suggest that debris flows may have contributed sediment to these deposits. This suggestion is based on the fact that small debris flows do occur in the area and that debris flows have been a source of large boulders 
in alluvial fans and valley floor alluvium in many places in the canyons of the Front Range and in the piedmont slope deposits along the mountain front. Yet, direct evidence of debris flows in the form of levees or concentrations of cobbles and boulders outlining the traces of former levees or lobes were not found on either diamicton. Unfortunately, exposures of the internal character of the diamictons do not exist, and the 1-and 2-m-deep fabric-study pits did not reveal much. Consequently, the role of debris flow activity in forming these diamictons is a matter of speculation. It is considered improbable that the diamictons are primarily debris flows, but probable that debris flows contributed some part of the diamictons.

\section{GLACIAL TRANSPORT}

Most properties of the diamictons on Niwot Ridge and the unnamed ridge to the north are consistent with a glacial origin. Their ridgetop locations are not unusual if the transporting agent was glacier ice, nor is the small amount of Tertiary rock in the diamictons unusual. Till composition at a given point can be out of phase with bedrock. For example, where till overlies the Tertiary stock, it is chiefly Proterozoic rock debris derived from farther west; yet where it overlies Silver Plume Quartz Monzonite $5 \mathrm{~km}$ east of the stock, it is dominated by rock types from the stock. Hence, what would be a compositional anomaly for slow mass movement is not anomalous for glacial transport.

The diamictons on Niwot Ridge and the unnamed ridge resemble till and are clearly different from nearby residuum in terms of the size and abundance of boulders present, sorting, and clast roundness (figs. $8-10)$. The difference in roundness between the clasts in the diamictons and those in till (fig. 10) are attributed to differences in distance of transport, the till having been transported twice as far as the diamictons.

As shown in figure 17, the graphic mean of grain size plotted against inclusive standard deviation (Folk and Ward, 1957) for the less-than-2 mm fraction of the diamictons on Niwot Ridge and the unnamed ridge produces a distribution of points similar to that plotted for till. However, the data plotted for the diamictons also overlap the distributions plotted for alluvial fan and mudflow deposits by Landim and Frakes (1968). The fans and mudflows were derived from different rock types than the diamictons of this paper and in different weathering environments. Data from them was included only to reinforce the point that poor sorting does not necessarily discriminate between alluvial and glacial deposits.

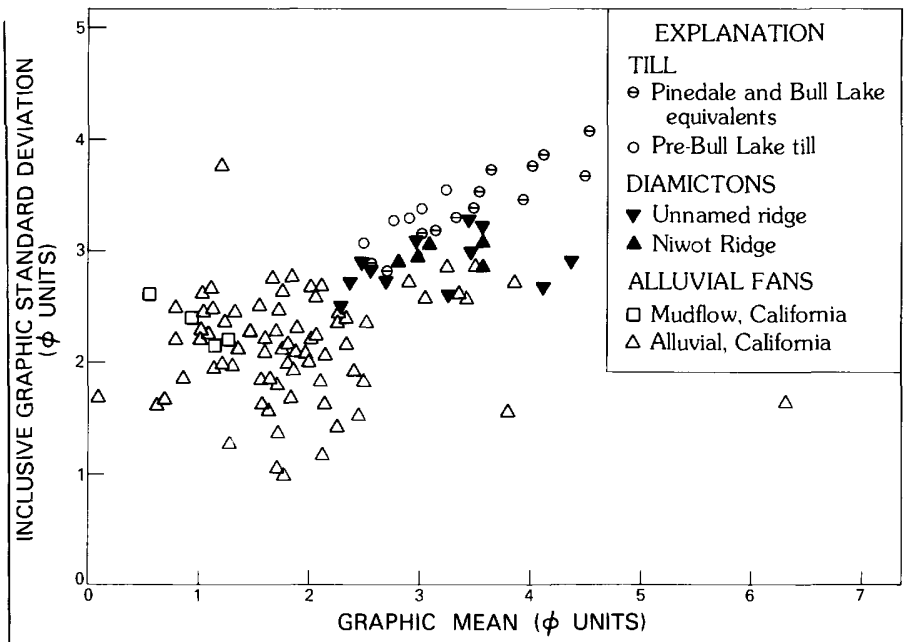

FIGURE 17.-Comparison of sorting, graphic mean plotted against inclusive graphic standard deviation after Folk and Ward (1957). Values for alluvial fans and ancient mudflows are from Landim and Frakes (1968). The diamictons on Niwot Ridge and the unnamed ridge to the nor th are generally better sorted than tills of Pinedale and Bull Lake age in nearby valleys, but have smaller mean sizes (larger phi values) than most of the alluvial fan deposits.

The surface features of quartz grains from the diamictons on Niwot Ridge and the unnamed ridge are similar to those of quartz grains from till and are unlike the surface features of quartz grains from residuum. (See table 5.) However, the parallel steps and arc-shaped steps that are abundant on grains from till and from the diamictons on Niwot Ridge and the unnamed ridge are not unique to glacial environments. Surface features that resemble those on quartz grains from glacial environments have been found on quartz grains from beach deposits in Florida and California (Setlow and Karpovich, 1972; Ingersoll, 1974), although in neither place are they as abundant as on grains from glacial environments. Brown (1973) also described surface features on quartz grains from nonglacial environments that were listed as glacial features by Krinsley and Donahue (1968). Apparently, grains with high relief and abundant parallel and arc-shaped steps are produced in more than one depositional environment. As noted by Brown (1973), the probable common ingredients of these environments are high energy, a high degree of mechanical abrasion, and a wide range of particle sizes.

Not enough electron microscopy has been done on quartz grains from landslide deposits and from highenergy fluvial deposits to know whether or not grains with high relief and abundant parallel and arcuate 
steps are also common in them. None of the features considered to be diagnostic of river environments by Margolis and Kennett (1971) were observed on any grains from the diamictons on Niwot Ridge and the unnamed ridge.

The unit of very fine sand and silt that trends diagonally across the unnamed ridge adjacent to the diamicton is consistent with a glacial origin. Melt water flowing between the ice and the topographic rise on the northeast could account for the channel form and the much better sorting of sediments.

A glacial origin is a possibility for the diamicton on the unnamed ridge. The position of this diamicton in the landscape (only $75 \mathrm{~m}$ above the level reached by late Pleistocene valley glaciers) and its alinement with the valley containing Blue Lake, at the head of which are large cirques, make it easy to visualize valley glaciers of an earlier glaciation overtopping the ridge. As noted previously, the composition and fabric of this diamicton suggest that it was transported from a source 1-3 km to the northwest.

If the diamicton on Niwot Ridge is of glacial origin, then it probably would have been of an older glaciation than that which deposited the diamicton on the unnamed ridge, because it is $100-250 \mathrm{~m}$ higher than the diamicton on the unnamed ridge. The glacier also would have been considerably smaller than those of late Pleistocene time, because of its small accumulation area. Studies in many regions have demonstrated that the ratio of accumulation area to total glacier area (AAR) for the majority of steady-state equilibrium glaciers is between 0.6 and 0.7 (Andrews, 1975). Inasmuch as the accumulation area is characterized chiefly by erosion, and concomitantly, the general absence of depositional features, the diamicton on Niwot Ridge would represent the ablation area, the remaining $0.3-0.4$ of the total glacier area. As is evident in figure 1 , if the diamicton on Niwot Ridge represents $0.3-0.4$ of the total area of the former glacier, there is barely enough space between the Continental Divide (the approximate upper limit of the inferred accumulation area) and the western limit of the diamicton to accommodate the accumulation area. This limited area for glacier accumulation precludes the possibility that the diamicton on Niwot Ridge was deposited by glaciers as large as or larger than those of late Pleistocene time.

The close proximity of the diamicton on Niwot Ridge to the summit of the range is a problem for the glacial hypothesis in view of the limitations imposed by a consideration of glacier AAR. Whether or not the diamicton on Niwot Ridge is but a remnant of the original deposit makes little difference. If the diamicton originally extended farther west, even less space would be available for the inferred accumulation area, and if it originally extended farther east, a larger space would be required for the accumulation area. Enlarging the diamicton in either direction would push the upper limit of the accumulation area west of the present location of the Continental Divide. This would not help the argument for a glacial origin, because the ice west of the divide would flow west and not be part of the accumulation area for the glacier that deposited the diamicton on Niwot Ridge. Hence, it is difficult to argue for a glacial origin for this deposit, except perhaps by a very small glacier.

It is doubtful that the position of the summit of the Front Range in the vicinity of Niwot Ridge has changed much if at all during Pleistocene time, although the position of the Continental Divide probably has shifted. Over most of the St. Vrain drainage basin, the preglacial position of the Continental Divide probably lay 2-4 km east of its present position. Now, most of the axial portion of the preglacial summit is gone and east-facing cirques and deep U-shaped valleys cut into westward-sloping remnants of the preglacial summit. The Continental Divide now follows the upper edge of these westward-sloping remnants and small portions of the former summit remain as isolated peaks (Mount Audubon, St. Vrain Mountain, Copeland Mountain, for example) above and to the east of the Continental Divide. A more easterly position for the divide in early Pleistocene time, of course, would make it even more difficult to reconcile the distribution of the diamicton on Niwot Ridge and a glacier with a typical AAR.

The argument that the diamicton is but a remnant of a Tertiary glacial deposit, existing in a landscape so modified from the one in which it was deposited that the limitations imposed by the AAR are irrelevant, is not justified from what is known about the Cenozoic history of the region. First, no evidence exists for a pre-Quaternary glaciation. The Tertiary paleoclimate deduced thus far from pollen and other fossils, both plant and animal, would not have been conducive to glaciation (Leopold and MacGinitie, 1972, p. 185-187). Moreover, the tectonic history recorded in the Southern Rocky Mountains suggests that the lofty summits glaciated during the Quaternary did not exist prior to Pliocene-Pleistocene time (Buffler, 1967; Izett, 1975; Larson and others, 1975; and Taylor, 1975). Therefore, if the diamicton on Niwot Ridge is a till, it probably would be of Quaternary age.

Second, Scott(1975), who has worked extensively on 
Tertiary and Quaternary erosion surfaces and deposits in the Southern Rocky Mountains, has found that in montane areas Quaternary erosion surfaces are narrow and are not more than $140 \mathrm{~m}$ above stream level. This amount of erosion and dissection, which is a maximum for Quaternary time, is not sufficient to invert the topography or rearrange the landscape to such an extent that the limitations of the glacier AAR can be ignored.

\section{ALLUVIAL-COLLUVIAL DEPOSITS}

It can be argued that the diamictons on Niwot Ridge and the unnamed ridge to the north are aggregations of alluvium, colluvium, and debris flow deposits, which were laid down on a surface that has since been faulted, uplifted, and deeply dissected. It is not likely that the streams involved were large inasmuch as the drainage divide of today is probably not far from the divide that existed when the diamictons were deposited. The surface upon which the diamictons were deposited may have been of low relief, and that portion of the diamicton shown in figure 16 may represent a remnant of the apex of a pediment. The diamictons could be analogs to the boulder gravels of Pleistocene age that cap mesas and high benches along the mountain front to the east.

Initially, the idea that the diamictons on Niwot Ridge and the unnamed ridge contained large amounts of alluvium was considered unlikely for two reasons. First, they seemed too coarse and poorly sorted, and second, if the diamicton on Niwot Ridge was deposited

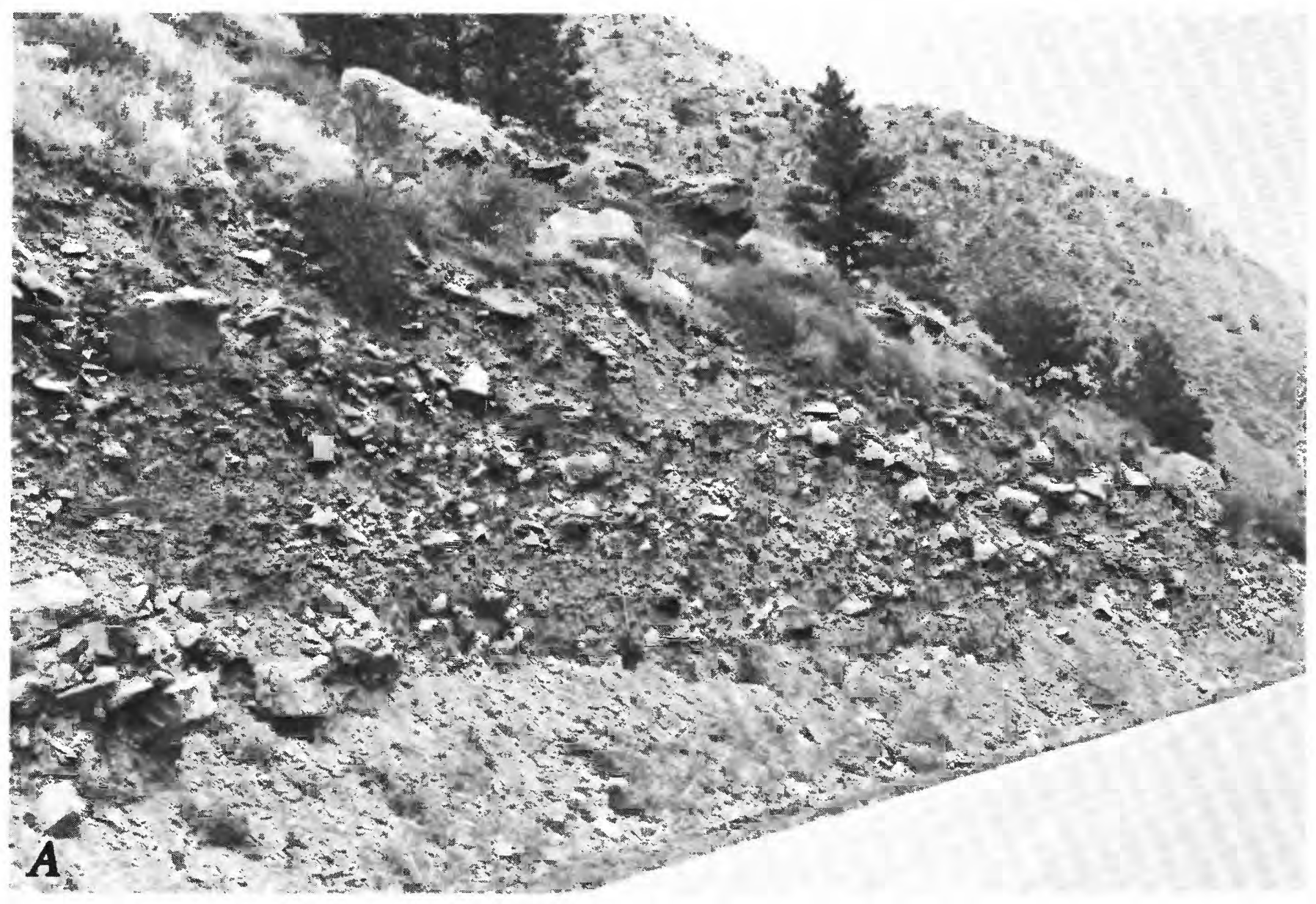

Figure 18. (above and facing page).-Deposits of alluvium and colluvium on canyon floor of Cachela Poudre River. $A$, Poorly sorted,crudely stratified deposit of alluvium and colluvium in the west-central part of the Big Narrows $7^{1} / 2^{\prime}$ quadrangle, Larimer County, Colo. (See fig. 19 for location.) Greater abundance of large boulders on the surface compared to within the sediment is typical of these deposits, which might explain why boulders are even more abundant on the diamicton on Niwot Ridge than they areon tills in neighboring valleys(fig.8). Shovel(1.45 m long) near center for scale. $B$, Fluvial deposit in the central part of the Big Narrows $7^{1} / 2^{\prime}$ quadrangle, Larimer County, Colo. This deposit is better sorted and contains more rounded clasts than that in $A$, indicating that it, unlike $A$, was deposited by the main stream. Boulders at top probably derived locally, chiefly from valley sides like most of the deposit shown in $A$. 


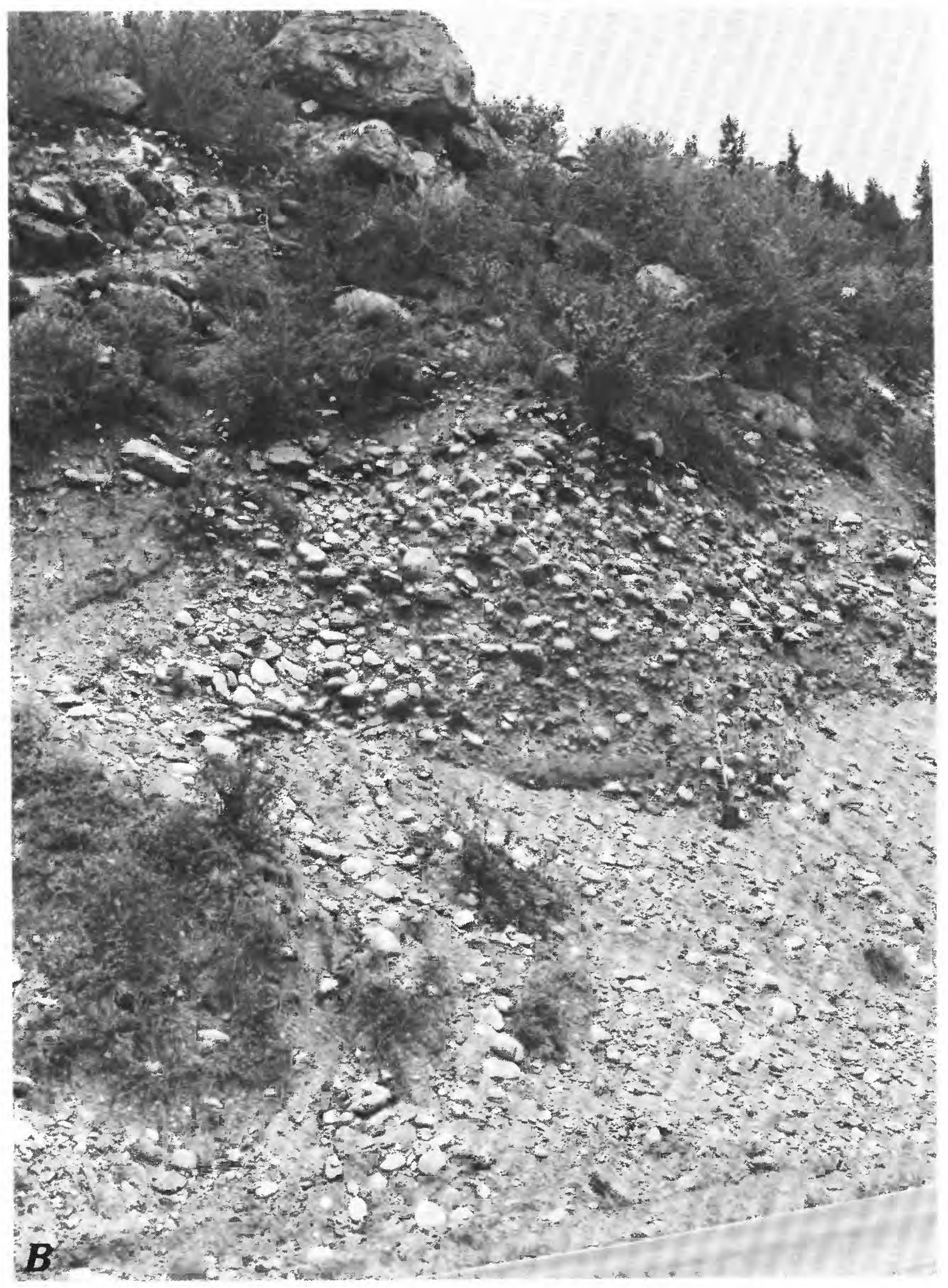


on a valley floor, then a significant topographic inversion has occurred in an area underlain by durable crystalline rocks. Nonetheless, neither of these reasons eliminates the possibility that alluvium is a major component of the diamictons.

Two comparisons, one with data for till and alluvial fans (fig. 17) and a second with deposits in the canyons of the Front Range, suggest that the diamictons are not too poorly sorted to be alluvium. As shown in figure 17, grain-size data for the diamictons on Niwot Ridge and the unnamed ridge overlap the distributions plotted for both till and alluvial fan deposits. Moreover, the matrix of the diamictons on Niwot Ridge and the unnamed ridge is better sorted than that of the tills in neighboring valleys, even though both types of deposits were derived from similar rocks and residuum.

Deposits of alluvium and colluvium similar to the diamicton on Niwot Ridge are common in most of the larger canyons along the east slope of the Front Range. Although the two localities shown in figure 18 are both from the canyon of the Cache la Poudre River, they are representative of the region as a whole. The deposit shown in figure $18 \mathrm{~A}$ contains a high percentage of colluvium and is much more like the diamictons on Niwot Ridge and the unnamed ridge than the deposit in figure $18 B$, which is better sorted, better stratified, and contains more rounded clasts. Crude stratification is evident at some localities in fluvial deposits of the type shown in figure $18 \mathrm{~A}$, but stratification is generally only apparent in large exposures such as shown in these photographs. Commonly, large boulders are more abundant on the surface than within the deposit (fig. 18A, $B$ ), a characteristic apparently shared by the diamictons. Most of the large boulders in figure $18 \mathrm{~A}$ are presumed to have been derived by rockfall, and thereafter, moved short distances by floods or by creep or other rockfalls.

In recent years, work in the Front Range has demonstrated that poorly sorted alluvium containing boulders $2-3 \mathrm{~m}$ long is relatively common. Three characteristics of these deposits are noteworthy: the majority (1) occur on ridge crests, $125-400 \mathrm{~m}$ above nearby valley floors; (2) lie well beyond the limit of Pleistocene glaciation; and (3) trend approximately parallel and relatively close to the major present-day streams (fig. 19). Figure 20 shows the surface and internal characteristics of one of these deposits (northeast quarter of quadrangle 3, fig. 19), which are similar to those of the deposit in figure $18 \mathrm{~A}$.

Although most of the deposits of figure 19 are beyond the glacial limit, those in quadrangle 4 (Tungsten quadrangle) are near the limit and those on Niwot Ridge and the unnamed ridge to the north (Ward quadrangle) are within the limit. The deposits in both quadrangles have been mapped as till (Wahlstrom, 1940, 1947; Ives, 1953; Madole, 1960, 1963; Bonnett, 1970; Gable, 1972). Van Tuyl and Lovering (1935), however, assigned a fluvial origin and a pre-Pleistocene age to the deposits in quadrangle 4 , which is the interpretation favored here for the dimictons on Niwot Ridge and the unnamed ridge.

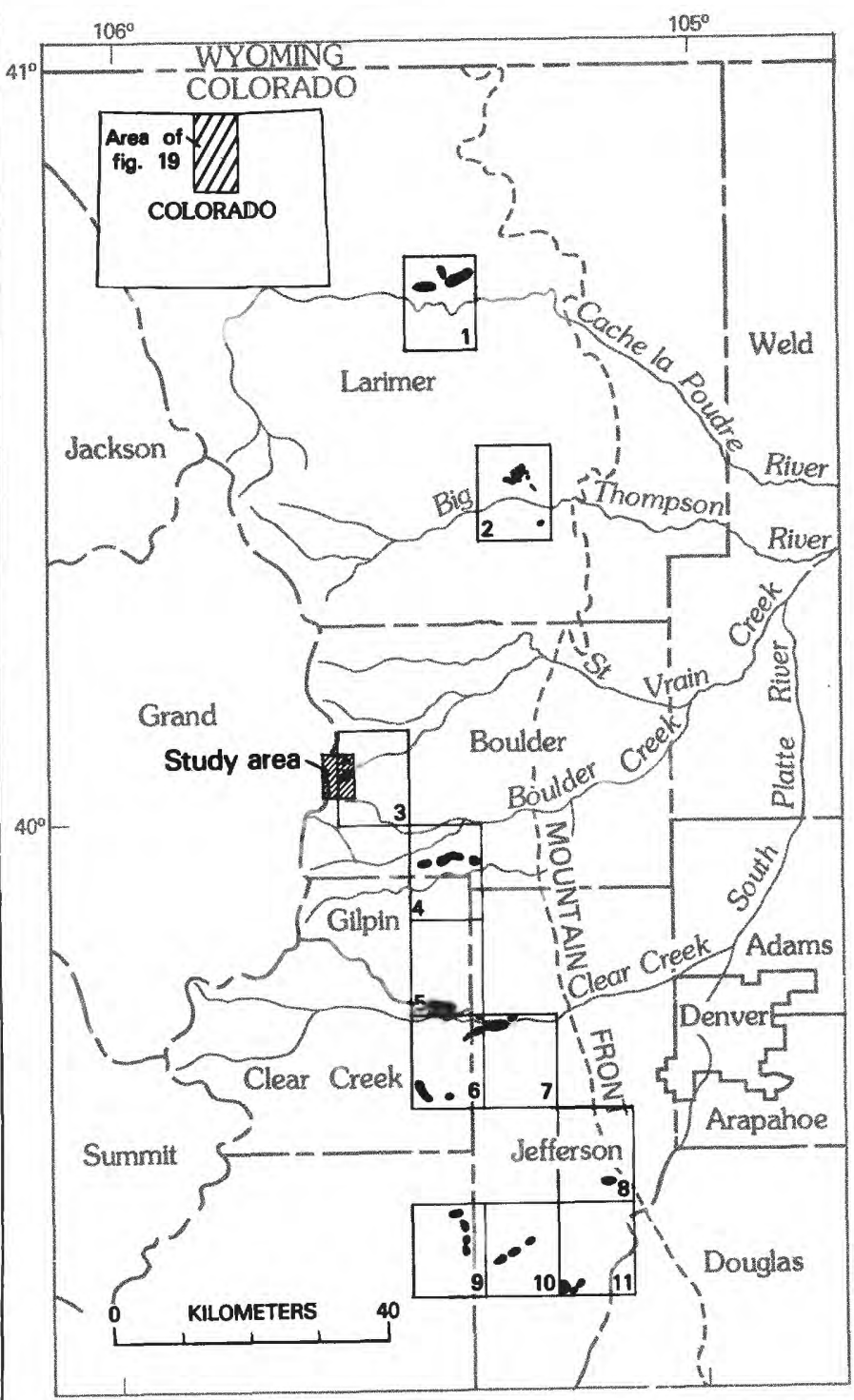

FIGURE 19.-Approximate locations of diamictons (in black) in and near the study area that, except in quadrangles 3 and 4 , have been mapped as Tertiary boulder or stream deposits. The deposits in quadrangles 3 and 4 previously have been mapped as till. Quadrangle names and corresponding geologic maps: 1, Big Narrows (Abbott, 1976); 2. Drake (Braddock and others, 1970); 3, Ward (Gable and Madole, 1976); 4, Tungsten (Gable, 1972); 5 , Black Hawk (Taylor, 1976); 6. Squaw Pass (Sheridan and Marsh, 1976); 7, Evergreen (Sheridan and others, 1972); 8, Indian Hills (Bryant and others, 1973); 9, Bailey (Bryant, 1976); 10, Pine (Bryant, 1974); 11, Platte Canyon (Peterson, 1964). 
The deposits on these ridges could be equivalent to the boulder alluviums whose distribution is shown in figure 19.

\section{SUMMARY}

Transport by slow mass movement in a periglacial environment is rejected as an origin for the diamictons on Niwot Ridge and the unnamed ridge to the north. Beyond that, however, it is difficult to prove or disprove any theory of the origin of these deposits.

The theory of origin by rockfall and rockslide avalanching has several weaknesses, and the conditions required for large debris flows seem to be absent in the crystalline core of this part of the Front Range. However, lack of exposures in which to see primary structures and the possibility that the deposits may be so old that diagnostic landforms have been obliterated by erosion and mass movement make it impossible to rule out origin by landsliding. Still, no evidence exists to indicate that large-scale landsliding has occurred in this part of the Front Range in the past or that the conditions necessary for it exist here. Although the diamictons are not believed to be chiefly debris flow deposits, this process may have contributed sediment to them.

As noted earlier, the diamictons on both Niwot Ridge and the unnamed ridge previously have been mapped as till. A glacial origin is a possibility for the diamicton on the unnamed ridge because of its location and lower altitude, but the probability that the diamicton on Niwot Ridge is till is considered to be very low. The evidence against this origin is greater than that against an origin by landsliding. Particularly difficult to explain by a glacial origin is the presence of extensive, thick deposits so close to the highest part of the glacier accumulation area. If a glacier were the transporting agent, it was a small ice mass. No evidence exists to indicate whether such an ice mass might have been part of a small ice cap or a valley glacier that originated in a cirque.

The principal conclusion of this report is that the diamictons on Niwot Ridge and the unnamed ridge to the north are not demonstrably glacial as previously thought, and that another explanation might explain them as well or better. Even though the evidence does not prove the specific mode of origin of the diamictons, it does permit development of three arguments that favor the interpretation that they are remnants of deposits of alluvium and colluvium.

The first argument is based on the physical resemblance of the diamictons on Niwot Ridge and the unnamed ridge to bouldery deposits of alluvialcolluvial origin. The diamictons on Niwot Ridge and the unnamed ridge are physically similar to the boulder gravels on canyon interfluves (fig. 20), on canyon floors (fig. 18A), and on mesas and benches along the mountain front. All three occurrences of boulder gravels are known to be nonglacial, and the last two are known in places to consist of mixtures of alluvium, colluvium, and mudflow deposits. The boulder gravels demonstrate that poorly sorted sediments containing large boulders of exotic rock types and resembling till are produced in fluvial environments and on piedmont slopes. The boulder gravels along the present mountain front demonstrate that large boulders have been transported several kilometers over low-gradient surfaces from small drainage basins. The boulder gravels on canyon interfluves demonstrate that older surfaces of deposition formerly existed and that either a topographic inversion of considerable magnitude has occurred or a surface of low relief was relatively widespread in the Front Range during the time when the boulder gravels (fig. 19) were deposited. The boulder gravels on canyon interfluves could be either valley floor deposits or remnants of sediment that once veneered a surface of low relief, possibly a pediment, that has since been uplifted and dissected.

The second argument is based on the occurrence of diamictons like those on Niwot Ridge and the unnamed ridge in areas where glaciation cannot account for them. Bouldery diamictons are common on interfluves in many parts of nonglaciated, mountainous Colorado. Not only do they occur in many parts of the Front Range, as shown in figure 19, but they also occur in the Sangre de Cristo Mountains and Wet Mountains (Scott, 1975; Taylor, 1975) and the Park Range, Never Summer Range, and Medicine Bow Mountains (R. F. Madole, unpub. mapping, 1980).

Even more important to this argument are the diamictons in the col at Pawnee Pass and the col between Pawnee Peak and Mount Toll, locations on the Continental Divide (fig. 1). If the diamictons on Niwot Ridge and the unnamed ridge are of the same origin as the diamictons in the cols, as their physical resemblance suggests, then they are not the product of glaciation. Judging from debris exposed in nivation hollows and on slopes, the diamictons in the cols are several tens of meters thick. Their locations and thicknesses are incompatible with a glacial origin because they are in what would have been the uppermost part of the glacier accumulation area, an area of erosion rather than deposition.

These diamicton-filled cols are not isolated occurrences Others were mapped farther north (Madole, 1963), and, although it is not on the Continental Divide, 
the saddle between Kiowa Peak and Mount Albion (figs. 1,2) contains another deposit of this kind. These diamictons are believed to be valley fills at the head of an ancestral drainage system.

The third argument concerns the amount of erosion that has occurred since deposition of the diamicton on Niwot Ridge. The amount of erosion seems to be too great to be solely the product of Quaternary time. Scott (1975), in summarizing the Cenozoic erosional and depositional history of the Southern Rocky Mountains, assigned a Tertiary age to gravels that are more than $108 \mathrm{~m}$ above present stream level. Because the valleys adjacent to Niwot Ridge are a product of glacial erosion as well as stream erosion, Scott's criteria for age assignment are not directly applicable. However, even if the amount of erosion in Quaternary time were twice as great in glaciated areas as in the nonglaciated areas, the diamicton on Niwot Ridge would still be assigned a Tertiary age because its midpoint is approximately $275 \mathrm{~m}$ above the valley on the south and $440 \mathrm{~m}$ above the valley on the north.

In conclusion, the diamictons on Niwot Ridge and the unnamed ridge and the one in the saddle between Kiowa Peak and Mount Albion, as well as most of the others on ridge crests and in cols along the summit of the northern Front Range are believed to be aggregations of alluvium, colluvium, and debris flow deposits that accumulated during Tertiary time. I disagree with the glacial origin and Quaternary age previously assigned to the diamictons on Niwot Ridge and the unnamed ridge, but I agree with Wahlstrom (1947) that they were deposited on surfaces developed in Tertiary time that later were uplifted and deeply dissected.

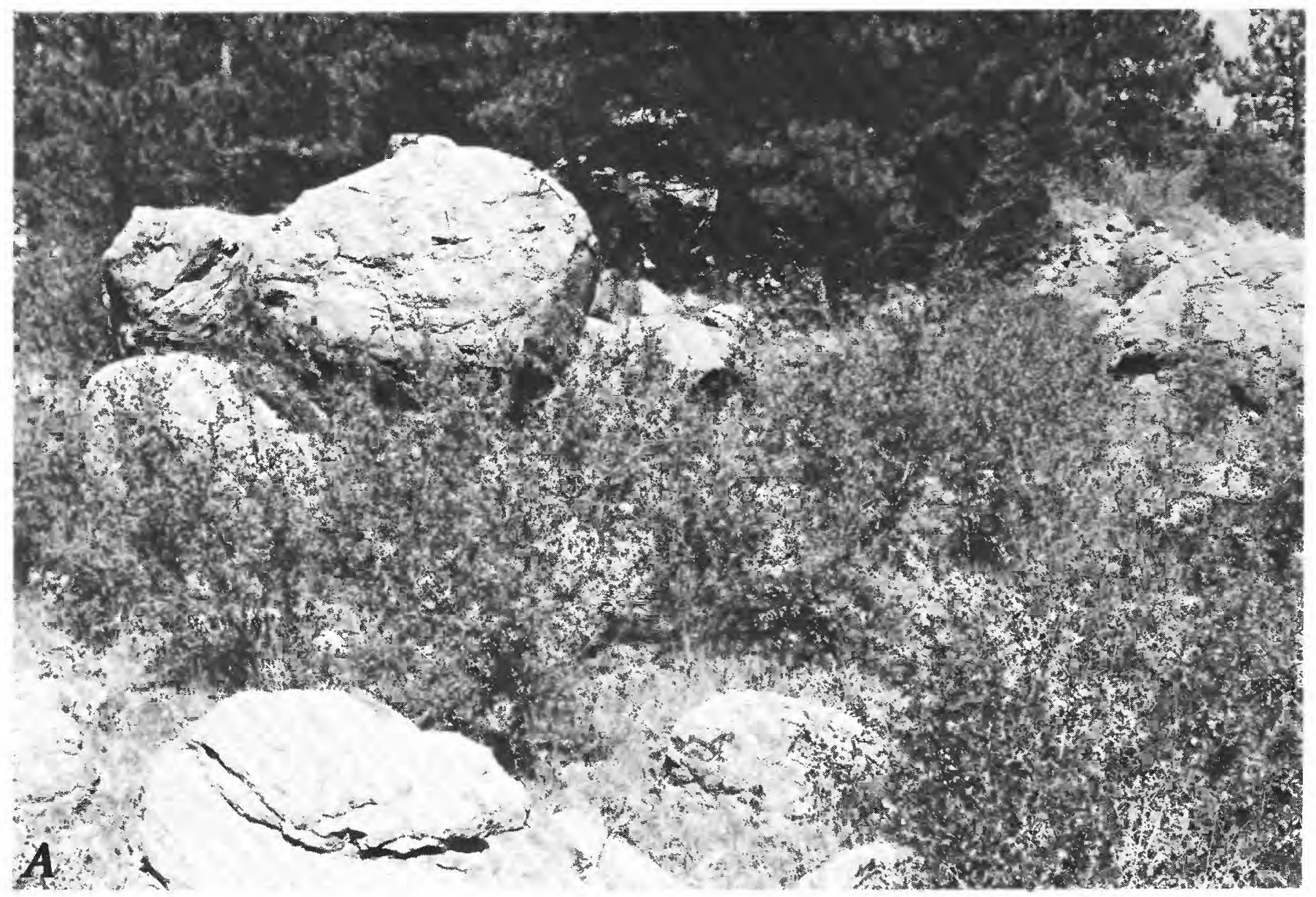

FIGURE 20.-Diamicton mapped as boulder gravel (Sheridan and Marsh, 1976) caps a ridge 120-135 m above Soda Creek and Beaver Brook in northeast Squaw Pass $7^{1} / 2^{\prime}$ quadrangle, Jefferson County, Colo. $A$, Bouldery surface of deposit. $B$, Exposure of deposit in a pit on southeast flank of ridge. 


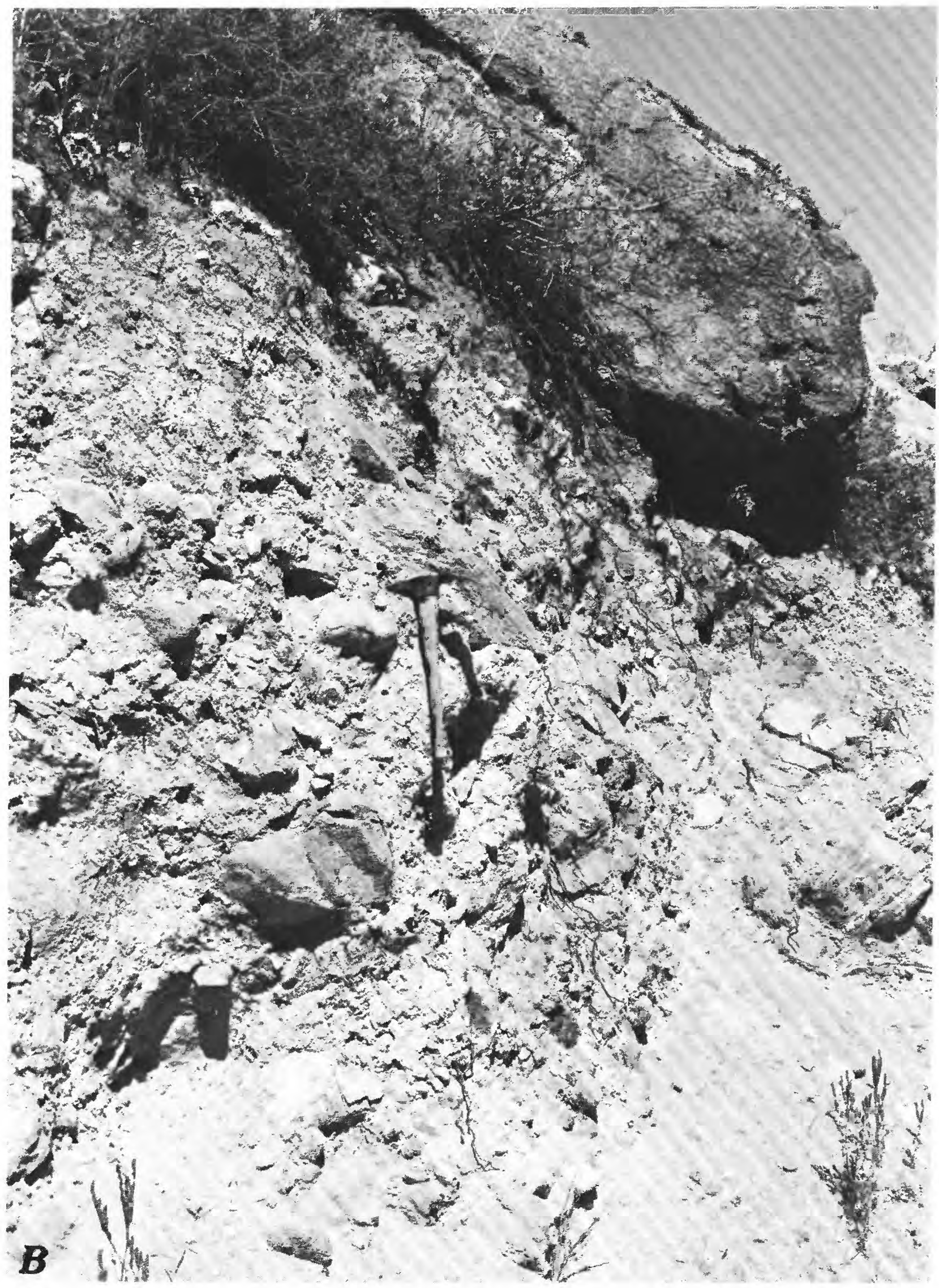




\section{REFERENCES CITED}

Abbott, J. T., 1976, Geologic map of the Big Narrows quadrangle, Larimer County, Colorado: U.S. Geological Survey Geologic Quadrangle Map GQ-1323.

Andrews, J. T., 1971, Techniques of till fabric analysis: British Geomorphology Research Group, Technical Bulletin 6, 43 p. 1975, Glacial systems-an approach to glaciers and their envoronments: North Scituate, Mass., Duxbury Press, 191 p.

Andrews, J. T., and Shimizu, K., 1966, Three-dimensional vector technique for analyzing till fabrics-discussion and Fortran program: Canada Department of Mines and Technical Surveys Geographical Bulletin, v. 8, no. 2, p. 151-165.

Andrews, J. T., and Smith, D. I., 1970, Till fabric analysismethodology and local and regional variability (with particular reference to the north Yorkshire till cliffs): Geological Society of London Quarterly Journal, v. 125, p. 503-542.

Atwood, W. W., and Mather, K. F., 1932. Physiography and Quaternary geology of the San Juan Mountains, Colorado: U.S. Geological Survey Professional Paper 166, 176 p.

Benedict, J. B., 1970, Downslope soil movement in a Coloradoalpine region-rates, processes, and climatic significance: Arctic and Alpine Research, v. 2, no. 3, p. 165-226.

Blank, R. G., and Margolis, S. V., 1975, Pliocene climate and glacial history of Antarctica as revealed by southeast Indian Ocean deep-sea cores: Geological Society of America Bulletin, v. 86, p. 1058-1066.

Bonnett, R. B., 1970, The glacial sequence of upper Boulder Creek drainage basin in the Colorado Front Range: Columbus, The Ohio State University Ph. D. dissertation, 318 p.

Braddock, W. A., Nutalaya, Prinya, Gawarecki, S. J., Curtin, G. C., 1970, Geologic map of the Drake quadrangle, Larimer County, Colorado: U.S. Geological Survey Geologic Quadrangle Map GQ-829.

Brown, J. E., 1973, Depositional histories of sand grains from surface textures: Nature, v. 242, p. 396-398.

Bryan, Kirk, and Ray, L. L., 1940. Geologic antiquity of the Lindenmeier site in Colorado: Smithsonian Miscellaneous Collection, v. 99, no. 2, 76 p.

Bryant, Bruce, Miller, R.D., and Scott, G. R., 1973 [1974], Geologic map of the Indian Hills quadrangle, Jefferson County, Colorado: U.S. Geological Survey Geologic Quadrange Map GQ-1073.

1976, Reconnaissance geologic map of the Bailey quadrangle, Jefferson and Park Counties, Colorado: U.S. Geological Survey Miscellaneous Field Studies Map MF-816.

Bryant, Bruce, Miller, R. D., and Scott, G. R., 1973 [1974, Geologic map of the Indian Hills quadrangle, Jefferson County, Colorado: U.S. Geological Survey Geologic Quadrangle Map GQ-1073.

Buffler, R. T., 1967, The Browns Park Formation and its relationship to the late Tertiary geologic history of the Elkhead region, northwestern Colorado-south-central Wyoming: Berkeley, University of California Ph. D. dissertation, $175 \mathrm{p}$.

Coch, N. K., and Krinsley, D. H., 1971, Comparison of stratigraphic and electron microscopic studies in Virginia Pleistocene coastal sediments: Journal of Geology, v. 79, p. 426-437.

Curry, R. R., 1966, Observations of alpine mudflows in the Tenmile Range, central Colorado: Geological Society of America Bulletin, v. 77 , no. 7, p. 771-776.

Endlich, F. M., 1876. Report [on the San Juan district, Colorado], in Hayden, F. V., Report of progress of the exploration for the year 1874-Colorado and parts of adjacent territories: U.S. Geological and Geographical Survey of the Territories, Annual Report, 8th, p. 181-240.
Eschman, D. F.. 1955. Glaciation of the Michigan River Basin, North Park, Colorado: Journal of Geology, v. 63, p. 197-213.

Flint, R. F., Sanders, J. E., and Rodgers, John, 1960a, Symmictitea name for nonsorted terrigenous sedimentary rocks that contain a wide range of particle sizes: Geological Society of America Bulletin, v. 71, no. 4, p. 507-510.

$1960 \mathrm{~b}$, Diamictite, a substitute term for symmictite [an addendum]: Geological Society of America Bulletin. v. 71, no. 12. p. $1809-1810$.

Folk, R. L., and Ward, W. C., 1957, Brazos River bar, a study in the significance of grain size parameters: Journal of Sedimentary Petrology, v. 27, p. 3-26.

Gable, D. J., 1972, Geologic map of the Tungsten quadrangle, Boulder, Gilpin, and Jefferson Counties, Colorado: U.S. Geological Survey Geologic Quadrangle Map GQ-978.

Gable, D. J., and Madole, R. F., 1976, Geologic map of the Ward quadrangle, Boulder County, Colorado: U.S. Geological Survey Geologic Quadrangle Map GQ-1277.

Harland, W. B., Herod, K. N., and Krinsley, D. H., 1966, The definition and identification of tills and tillites: Earth-Science Review, v. 2, no. 3, p. 225-256.

Harris, D. V., and Fahnestock, R. K., 1962, Lower Pleistocene Prairie Divide till, Larimer County, Colorado: U.S. Geological Survey Professional Paper 450-B, p. 45-47.

Howe, Ernest, 1909, Landslides in the San Juan Mountains, Colorado: U.S. Geological Survey Professional Paper 67, 58 p.

Ingersoll, R. V., 1974, Surface textures of first cycle quartz grains: Journal of Sedimentary Petrology, v. 44, p. 151-157.

Ives, R. L., 1953, Anomalous glacial deposits in the Colorado Front Range area, Colorado: American Geophysical Union Transactions, v. 34, no. 2, p. 220-226.

Izett, G. A., 1975, Late Cenozoic sedimentation and deformation in northern Colorado and adjoining areas, in Curtis. B. F., ed., Cenozoic history of the southern Rocky Mountains: Geological Society of America Memoir 144, p. 179-210.

Kamb, W. B., 1959, Ice petrofabric observations from Blue Glacier, Washington, in relation to theory and experiment: Journal of Geophysical Research, v. 64, p. 1891-1909.

Kennett, J. P., and Brunner, C. A., 1973, Antaretic late Cenozoic glaciation-Evidence for initiation of ice-rafting and inferred increased bottom-water activity: Geological Society of America Bulletin, v. 84, p. 2043-2052.

Krinsley, D. H., and Donahue, Jack, 1968, Environmental interpretation of sand grain surface textures by electron microscopy: Geological Society of America Bulletin, v. 79, no. 6, p. 743-748.

Krinsley, D. H., and Doornkamp, J. C., 1973, Atlas of quartz sand surface textures: London, Cambridge University Press, $91 \mathrm{p}$.

Krinsley, D. H., and Margolis, S. V., 1969, A study of quartz sand grain surface textures with the scanning electron microscope: New York Academy of Science Transactions, Series II, v. 31, no. 5, p. 457-477.

Krinsley, D. H., and Takahashi, Taro, 1964, A technique for the study of surface textures of sand grains with electron microscopy: Journal of Sedimentary Petrology, v. 34, p. 423-426.

Krinsley, D. H., Takahashi, Taro, Silberman, M., and Newman, W., 1964, Transportation of sand grains along the Atlantic shore of Long Island, New York-An application of electron microscopy: Marine Geology, v. 2, p. 100-121.

Landim, P. M. B., and Frakes, L. A., 1968, Distinction between tills and other diamictons based on textural characteristics: Journal of Sedimentary Petrology, v. 38, no. 4, p. 1213-1223.

Larson, E. E., Ozima, Minoru, and Bradley, W. C., 1975, Late Cenozoic basic volcanism in northwestern Colorado and its implications concerning tectonism and the origin of the Colorado 
River system, in Curtis, B. F., ed., Cenozoic history of the Southern Rocky Mountains: Geological Society of America Memoir 144, p. 155-178.

Lees, G., 1964, A new method for determining the angularity of particles: Sedimentology, v. 3, p. 2-21.

Leopold, E. B., and MacGinitie, H. D., 1972, Development and affinities of Tertiary floras in the Rocky Mountains, in Aham, A. G., ed., Floristics and paleofloristics of Asia and eastern North America: Amsterdam, Elsevier, p. 147-200.

Madole, R. F., 1960, Glacial geology of upper South St. Vrain valley, Boulder County, Colorado: Columbus, The Ohio State University M.S. thesis, $109 \mathrm{p}$.

1963, Quaternary geology of St. Vrain drainage basin, Boulder County, Colorado: Columbus, The Ohio State University $\mathrm{Ph}$. D. dissertation, $288 \mathrm{p}$.

1976, Glacial geology of the Front Range, Colorado, in Mahaney, W. C., ed., Quaternary stratigraphy of North America: Stroudsburg, Pa., Dowden, Hutchinson \& Ross, Inc., p. 297-318.

Madole, R. F., and others, 1973, Natural hazards, in Madole, R. F., ed., Environmental inventory and land use recommendations for Boulder County, Colorado: Institute of Arctic and Alpine Research, University of Colorado, Occasional Paper 8, p. 143-174.

Madole, R. F., Colman, S. M., and Ebaugh, W. F., 1974, Technical Report A, Geology, upper Williams Fork basin, in Preliminary environmental evaluation of expanding Williams Fork water diversion system: Denver, prepared by $\mathrm{CH} 2 \mathrm{M}$ Hill, Inc. for Denver Board of Water Commissioners, $90 \mathrm{p}$.

Margolis, S. V., and Kennett, J. P., 1971, Cenozoic paleoglacial history of Antarctica recorded in subantarctic deep-sea cores: American Journal of Science, v. 271, p. 1-36.

Margolis, S. V., and Krinsley, D. H., 1971, Submicroscopic frosting on eolian and subaqueous quartz sand grains: Geological Society of America Bulletin, v. 82, p. 3395-3406.

Moss, J. H., 1951, Early man in the Eden Valley [Wyoming]: University of Pennsylvania Museum Monograph 6, p. 9-92.

Pearson, R. C., and U.S. Bureau of Mines, 1980, Mineral resources of the Indian Peaks study area, Boulder and Grand Counties, Colorado: U.S. Geological Survey Bulletin 1463, 109 p.

Peterson, W. L., 1964, Geology of the Platte Canyon quadrangle, Colorado: U.S. Geological Survey Bulletin 1181-C, p. C1-C23.

Pettijohn, F. J., 1949, Sedimentary rocks: New York, Harper, 526 p.

Potter, R. E., and Pettijohn, F. J., 1977, Paleocurrents and basin analysis, 2nd corrected and updated edition: Berlin and New York, Springer-Verlag, $425 \mathrm{p}$.

Ray, L. L., 1940, Glacial chronology of the Southern Rocky Mountains: Geological Society of America Bulletin, v. 51, no. 12, p. 1851-1918.
Richmond, G. M., 1948, Modification of Blackwelder's sequence of Pleistocene glaciation in the Wind River Mountains, Wyoming [Abs]: Geological Society of America Bulletin, v. 59, no. 12, p. $1400-1401$.

1965, Glaciation of the Rocky Mountains, in Wright, H. E., Jr., and Frey, D. G., eds., The Quaternary of the United States: Princeton University Press, p. 217-230.

Robinson, C. S., Lee, F. T., Scott, J. H., Carroll, R. D., Hurr, R. T., Richards, D. B., Mattei, F. A., Hartman, B. E., and Abel, J. F., Jr., 1974, Engineering, geologic, geophysical, hydrologic, and rock mechanics investigations of the Straight Creek tunnel site and pilot bore, Colorado: U.S. Geological Survey Professional Paper 815, $134 \mathrm{p}$.

Scott, G. R., 1975, Cenozoic surfaces and deposits in the southern Rocky Mountains and their recognition, in Curtis, B. F., ed., Cenozoic history of the southern Rocky Mountains: Geological Society of America Memoir 144, p. 227-248.

Setlow, L. W., and Karpovich, R. P., 1972, "Glacial" micro-textures on quartz and heavy mineral sand grains from the littoral environment: Journal of Sedimentary Petrology, v. 42, no. 4, p. 864-875.

Sheridan, D. M., and Marsh, S. P., 1976, Geologic map of the Squaw Pass quadrangle, Clear Creek, Jefferson, and Gilpin Counties, Colorado: U.S. Geological Survey Geologic Quadrangle Map GQ-1337.

Sheridan, D. M., Reed, J. C., Jr., and Bryant, Bruce, 1972, Geologic map of the Evergreen quadrangle, Jefferson County, Colorado: U.S. Geological Survey Miscellaneous Geologic Investigations Map I-786-A.

Shreve, R. L., 1968, The Black Hawk Landslide: Geological Society of America Special Paper 108, 47 p.

Taylor, R. B., 1975, Neogene tectonism in south-central Colorado, in Curtis, B. F., ed., Cenozoic history of the Southern Rocky Mountains: Geological Society of America Memoir 144, p. 211-226.

1976, Geologic map of the Black Hawk quadrangle, Gilpin, Jefferson, and Clear Creek Counties, Colorado: U.S. Geological Survey Geologic Quadrangle Map GQ-1248.

Tweto, Ogden, and Sims, P. K., 1963, Precambrian ancestry of the Colorado mineral belt: Geological Society of America Bulletin, v. 74, p. 991-1014.

Van Tuyl, F. M., and Lovering, T. S., 1935, Physiographic development of the Front Range: Geological Society of America Bulletin, v. 46, p. 1291-1350.

Wahlstrom, E. E., 1940, Audubon-Albion stock, Boulder County, Colorado: Geological Society of America Bulletin, v. 51, no. 12, p. 1789-1820.

1947. Cenozoic physiographic history of the Front Range, Colorado: Geological Society of America Bulletin, v. 58, no. 7, p. 551-572. 